\title{
Hepatitis B and C viruses in the development of hepatocellular carcinoma
}

\author{
Ming-Whei Yu, Chien-Jen Chen* \\ Institute of Epidemiology, College of Public Health, National Taiwan University, No. 1 Jen-Ai Rd. Sec. 1, Taipei 10018, Taiwan
}

Accepted 9 November 1993

\section{Contents}

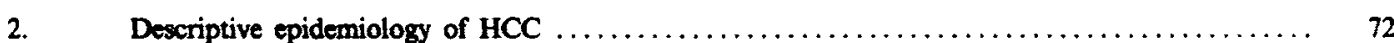

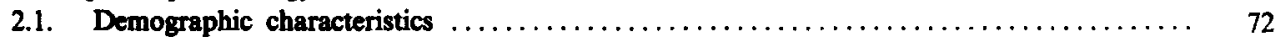

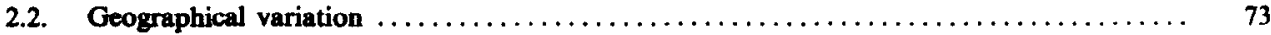

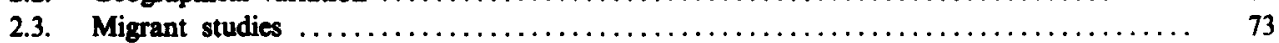

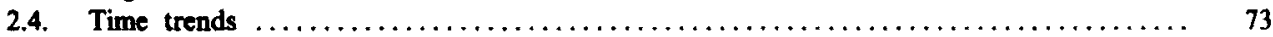

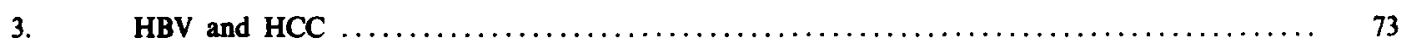

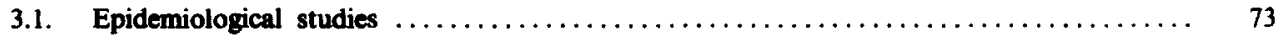

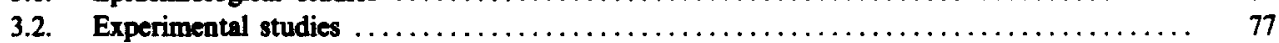

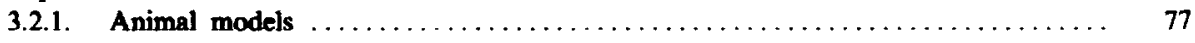

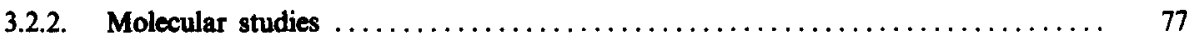

3.2.3. Possible mechanisms of HBV-related hepatocarcinogenesis $\ldots \ldots \ldots \ldots \ldots \ldots \ldots$. 78

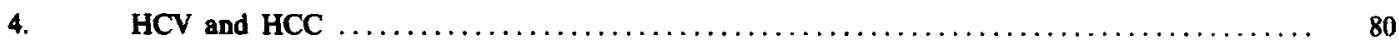

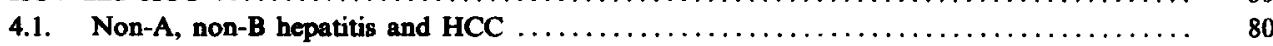

4.2. Anti-HCV in patients with chronic liver diseases or HCC $\ldots \ldots \ldots \ldots \ldots \ldots \ldots \ldots \ldots$

4.3. Epidemiological studies on the association of HCV with HCC $\ldots \ldots \ldots \ldots \ldots \ldots \ldots \ldots, 80$

4.4. Comparison and implication of anti-HCV assays $\ldots \ldots \ldots \ldots \ldots \ldots \ldots \ldots \ldots \ldots . . .62$

5. Interaction of HBV or HCV with other risk factors in the etiology of HCC ........... 84

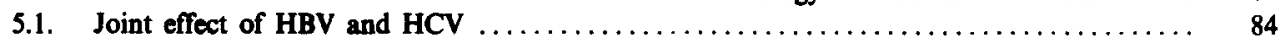

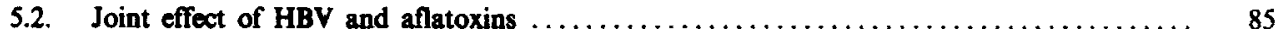

5.3. Interaction of $\mathrm{HBV}$ with alcohol drinking or cigarette smoking $\ldots \ldots \ldots \ldots \ldots \ldots \ldots \ldots \ldots, 86$

5.4. Interaction of $\mathrm{HCV}$ with alcohol drinking, cigarette smoking or hepatitis $\mathrm{D}$ virus $\ldots \ldots \ldots$

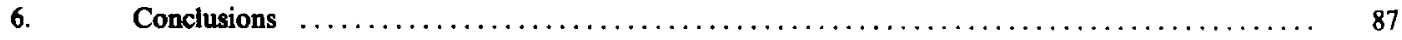

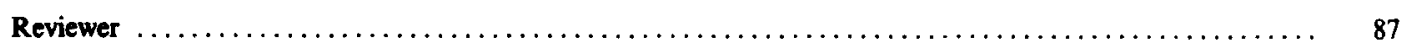

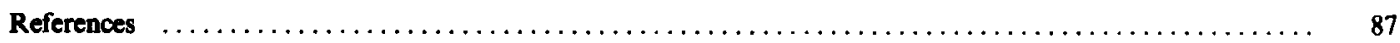

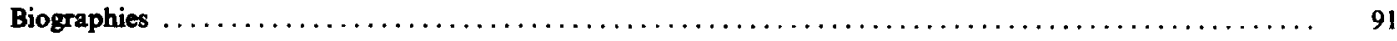

\footnotetext{
* Corresponding author. Tel. 8862393 4392; Fax. 88623511955.
} 


\section{Introduction}

The hypothesis that a virus may contribute to the development of cancer has been proposed since the 1910s [1]. Certain DNA- or RNA-containing viruses have been recognized as inducing tumors in animals [1]. Associations between human viruses and the induction of certain cancers have also been established on the basis of epidemiological, clinical, and molecular biological studies. Although there is substantial evidence suggesting the importance of certain subtypes of human papilloma virus in the development of cervical cancer, Epstein-Barr virus in the development of Burkitt's lymphoma and nasopharyngeal carcinoma, as well as HTLV-I in the pathogenesis of adult T-cell leukemia [2], among the human oncogenic viruses the link between hepatitis B virus (HBV) and hepatocellular carcinoma (HCC) is the strongest ever demonstrated.

$\mathrm{HCC}$ is one of the most common cancers in the world. However, there exists a striking geographic variation in its incidence throughout the world [3]. The highest incidence areas cluster in south-eastern Asia and subSaharan Africa. HBV has been well-documented as the major etiological factor of $\mathrm{HCC}$ in these areas where it accounts for $50-90 \%$ of the liver cancer cases.

A large proportion of $\mathrm{HCC}$ cases in developed countries have long been noted to have no detectable serological markers of HBV infection [4]. This implies that other risk factors may contribute to the pathogenesis of HCC. There were several convincing case reports that described the development of HCC following nonA, non-B transfusion-associated hepatitis [5-8]. However, the association between non-A, non-B posttransfusion hepatitis and HCC could be investigated only recently after the hepatitis $\mathrm{C}$ virus (HCV) genome had been cloned and specific assays for circulating antiHCV were developed [9]. HCV has been shown to be the main causative agent in parenterally transmitted non-A, non-B hepatitis [10]. The relative importance of $\mathrm{HCV}$ in the etiology of $\mathrm{HCC}$ has been particularly emphasized in Japan, Spain and Italy.

Although a vast majority of $\mathrm{HCC}$ cases has been attributed to persistent viral hepatitis infections, numerous data obtained from various epidemiological study designs suggest that other factors may also contribute to the development of HCC. A moderate excess risk of $\mathrm{HCC}$ has been associated with cigarette smoking and habitual alcohol drinking [11-15]. Recent nested case-control studies also suggested that aflatoxin exposure and elevated serum level of endogenous testosterone may play a significant role in the development of HCC $[16,17]$.

The evolution of $\mathrm{HCC}$ is a process of multiple stages with the involvement of multiple factors. HCC usually develops after several decades of persistent infection with $\mathrm{HBV}$ or HCV. The relatively long latency period between the initial viral infection and HCC development, as well as the fact that only a small fraction of infected individuals eventually develop HCC, implies that the virus itself may not be a sufficient cause for the development of HCC. Other factors may be required in the virus-related hepatocarcinogenesis. Researches aimed at the investigations of the interactions of $\mathrm{HBV}$ or $\mathrm{HCV}$ with other risk factors may provide further insight into the multifactorial etiology of HCC.

Viruses can contribute to the development of human cancers by a variety of mechanisms including stimulation of cell proliferation through viral oncogenes or causing cellular injury, insertional mutation, and immunosuppression [2]. A number of molecular biological and animal studies have provided important etiological insight into the mechanism of HBV-related hepatocarcinogenesis. However, many uncertainties about the precise mechanism in humans still exist. They continue to challenge scientists interested in the prevention, biology and therapy of HCC. The understanding of the role of $\mathrm{HCV}$ in the pathogenesis of $\mathrm{HCC}$ also remains primitive. The objective of this review is to address the sources of evidence concerning the roles of $\mathrm{HBV}$ and $\mathrm{HCV}$ in the etiology of HCC, with emphasis on the interactions between the viral infection and other HCC risk factors which have not been sufficiently evaluated.

\section{Descriptive epidemiology of HCC}

\subsection{Demographic characteristics}

In populations at an HCC risk ranging from the lowest to the highest, the incidence of HCC increases with age. However, the age-specific incidence of HCC differs appreciably in different geographical areas, especially between populations at very high and low risk [18]. In western countries, HCC is primarily a disease of the elderly, with most HCC patients diagnosed at ages 60 and older [19]. However, the ages shift markedly to the younger age groups in areas of high incidence. In much of Asia, the average age of those affected with HCC is around 50, and around 40 in Africa. In certain high risk areas of Africa, the age curve of HCC incidence peaks at 25 years of age and then shows a plateau with only a slight decline after 50 years of age [18]. Such an age curve suggests the existence of certain risk factors of HCC which may have a strong effect in childhood.

Men are more frequently affected with HCC than women. The sex discrepancy in HCC incidence is evident throughout the world $[3,19,20]$. In Taiwan, HCC is two- to three-times more frequent in men than in women, despite their similarity in $\mathrm{HBsAg}$ carrier rate [20]. Differences in sex hormone and life-style habits such as alcohol drinking and cigarette smoking have been implicated in the gender discrepancy $[11,17]$. 


\subsection{Geographical variation}

HCC is rare or uncommon in most parts of the world. However, this cancer is very common throughout subSaharan Africa and in many parts of the Far East $[3,21]$. Although the international geographical variation in the incidence of $\mathrm{HCC}$ has been correlated to the prevalence of HBsAg carrier status [3,21], these ecological correlation studies may be confounded by the aflatoxin exposure because the ingestion of foods contaminated with a relatively high level of aflatoxins is common in populations living in high risk areas. The variation in HCC incidence within countries may also be partly explained by variation in the prevalence of $\mathrm{HBsAg}$ carrier status $[3,22]$. However, HBsAg carrier rate may not readily explain all the intra- or international variation of $\mathrm{HCC}$ incidence. An ecological correlation study in Taiwan reported the mortality rate of liver cancer is significantly higher in the mountainous aborigines, Penghu Islets, and in endemic areas of blackfoot disease, a peripheral vascular disease induced by chronic arsenic exposure [20]. As the $\mathrm{HBsAg}$ carrier rate was only slightly higher in these areas than in the general population in Taiwan, other factors unique in these areas have been considered to play at least a partial role in the development of HCC.

\subsection{Migrant studies}

The extraordinarily high incidence of $\mathrm{HCC}$ among Chinese throughout the world is one of its most significant characteristics. In Singapore, the age-adjusted rate is higher in Chinese than in Indians and Malays. In San Francisco and Los Angeles, Chinese also have a significantly higher age-adjusted rate of liver cancer than blacks, whites and Japanese [20]. As most chronic HBV carriers among Chinese are infected with this virus during early childhood through vertical transmission, the consistently high $\mathrm{HCC}$ incidence among Chinese migrants supports the role of $\mathrm{HBV}$ in the etiology of HCC.

\subsection{Time trends}

An analysis of 37 populations from 18 countries with cancer registry systems showed a significant increase in HCC incidence among $17(46 \%)$ of the populations studied for men and among $10(27 \%)$ for women between 1956 and 1972 [23]. Improvement in the accuracy of diagnosis and registration might account for this increase during this period. In countries characterized by high prevalence of $\mathrm{HBsAg}$ carrier status such as Singapore, Hong Kong and Taiwan, the secular trend of HCC in recent years has shown different patterns. The HCC incidence remained relatively constant or slightly declined among both men and women between 1968 and 1982 in Singapore and Hong Kong [24,25]. In Taiwan, the age-adjusted mortality of liver cancer has increased among men during the same period, but remained stable among women [20]. As the HBsAg carrier rate is relatively stable for both men and women in Taiwan, the rising HCC trend for men suggests men in Taiwan may have either increasingly been exposed to environmental carcinogens other than chronic HBV infection or changed their life-style habits predisposing to the development of HCC. The most striking increase in the HCC incidence in recent decades was reported from a study in Japan in which a more than two-fold increase in HCC incidence was observed among men [26]. Non-A, non-B post-transfusional hepatitis has been considered as a possible cause of the increase in HCC incidence.

\section{HBV and HCC}

\subsection{Epidemiological studies}

Epidemiological studies have provided strong evidence for the association between chronic HBV infection and HCC. In the case-control studies, summarized in Table 1, the relative risk of developing HCC associated with $\mathrm{HBsAg}$ carrier status ranged from 5 to 20 . Our three previous case-control studies in Taiwan also reported a higher $\mathrm{HCC}$ risk for carriers of both $\mathrm{HBsAg}$ and $\mathrm{HBeAg}$ than for carriers of $\mathrm{HBsAg}$ alone $[11,31,32]$.

The causal relationship between chronic HBV infection and the development of $\mathrm{HCC}$ has been addressed in six cohort studies (Table 2). Two large cohort studies in Taiwan examined the association of $\mathrm{HBsAg}$ carrier status with $\mathrm{HCC}$ by comparing the $\mathrm{HCC}$ incidence among HBsAg carriers with a non-carrier control population $[15,39]$. In four cohort studies of $\mathrm{HBsAg}$ positive blood donors in Japan, and England and Wales, the observed number of deaths from HCC was compared with the expected number derived from the age, sex, and calendar time-specific mortality from this cancer in the general population [40-43]. The estimates of relative risk for HBsAg carrier status varied from 6 to 100 . The highest relative risk was reported from a prospective study of government employees in Taiwan [39]. This relative risk is much higher than those observed in our community-based cohort study in Taiwan [15] and several case-control studies in Hong Kong [29], mainland China [30] and Taiwan [11,31,32]. The explanation for this difference is not clear. Perhaps HCC risk factors other than chronic HBV infection are less common among government employees in Taiwan so the relative importance of $\mathrm{HBsAg}$ carrier status is higher.

The fraction of $\mathrm{HCC}$ attributable to $\mathrm{HBsAg}$ carrier status varies from $50 \%$ to more than $90 \%$ in high risk areas, $7-50 \%$ in intermediate risk areas, and less than $10 \%$ in low risk areas. The large variation in the attributable proportion varies strikingly from country to country and reflects the relative importance of chronic $\mathrm{HBV}$ infection in the etiology of HCC. 


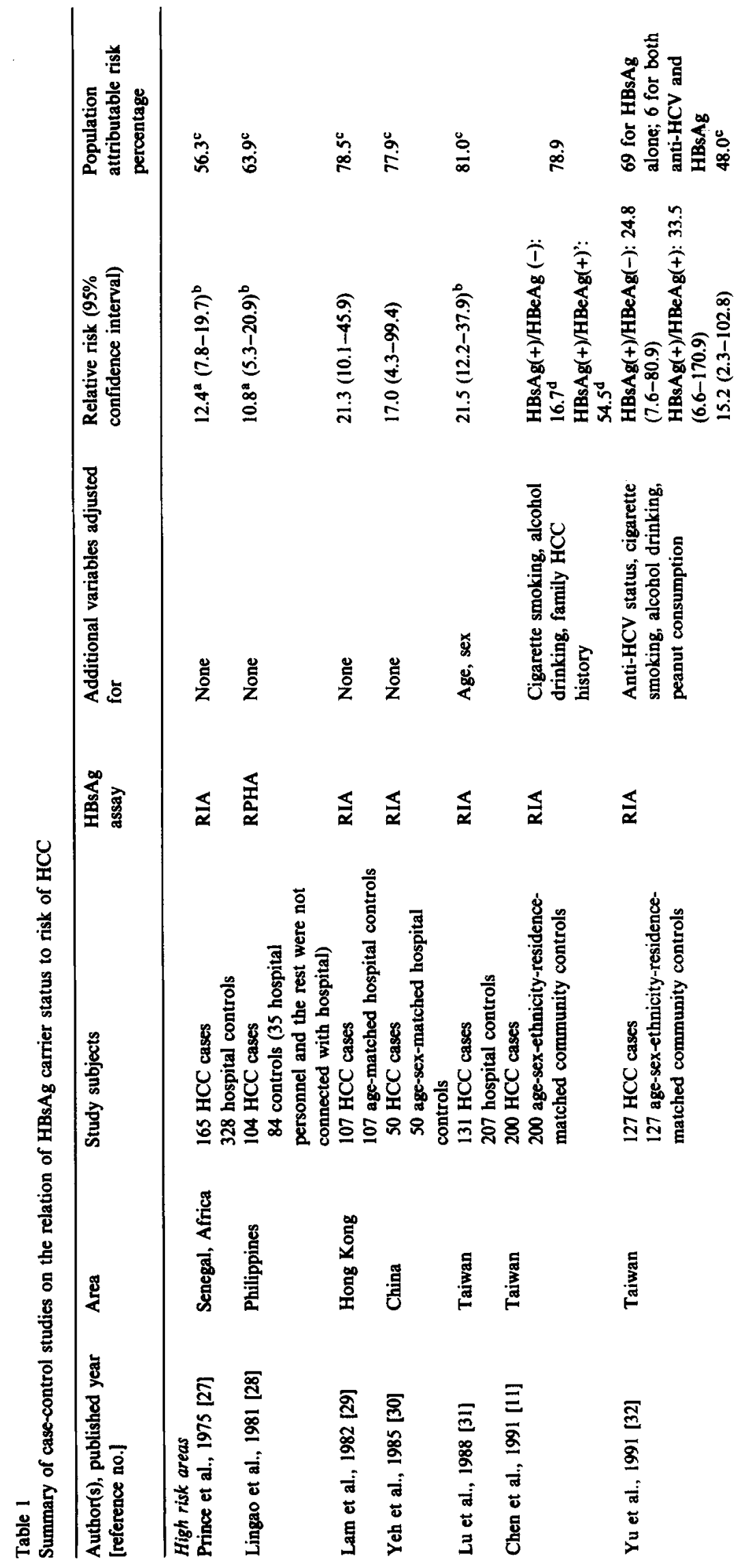



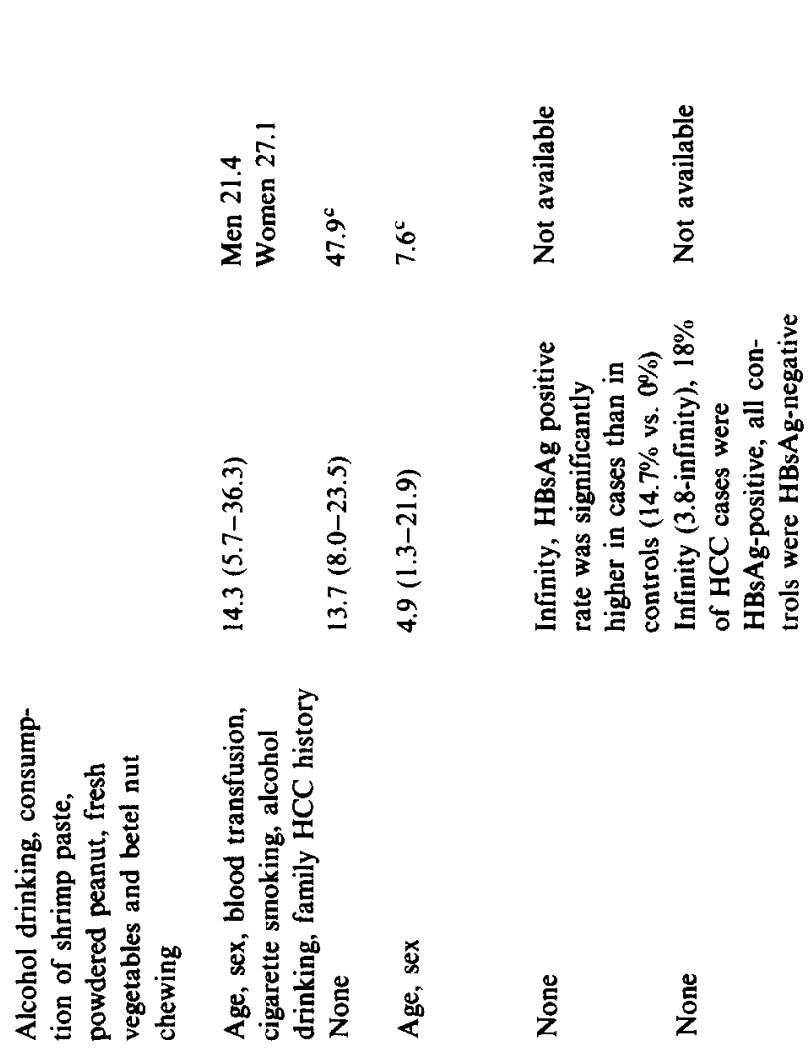

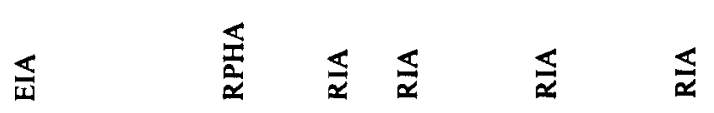

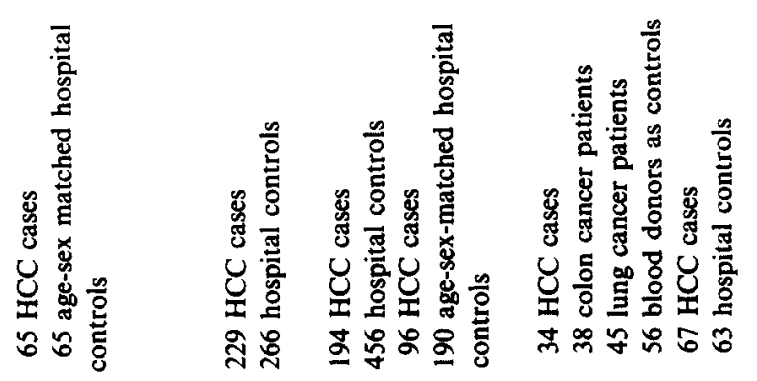

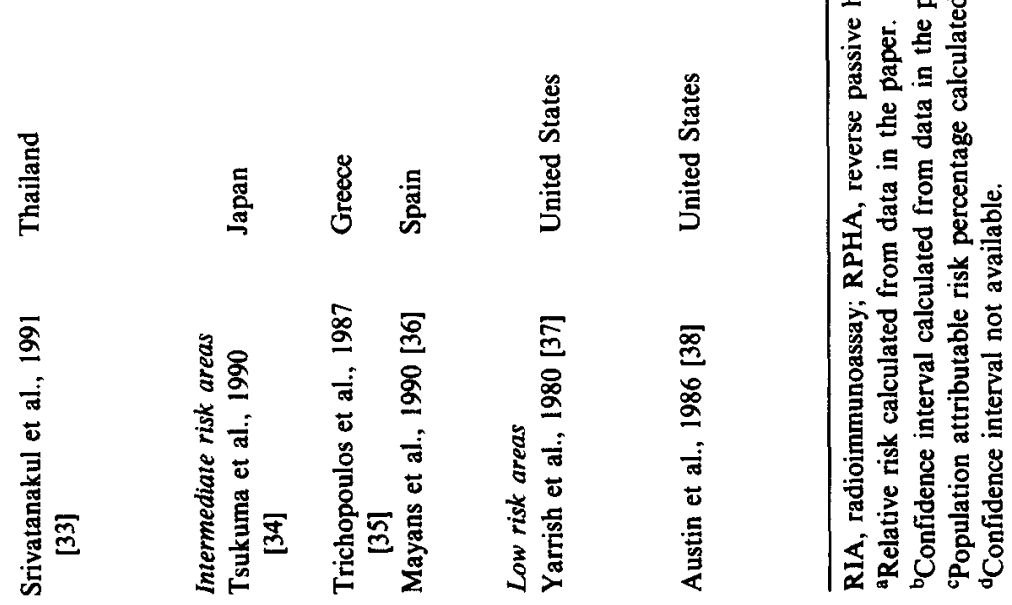




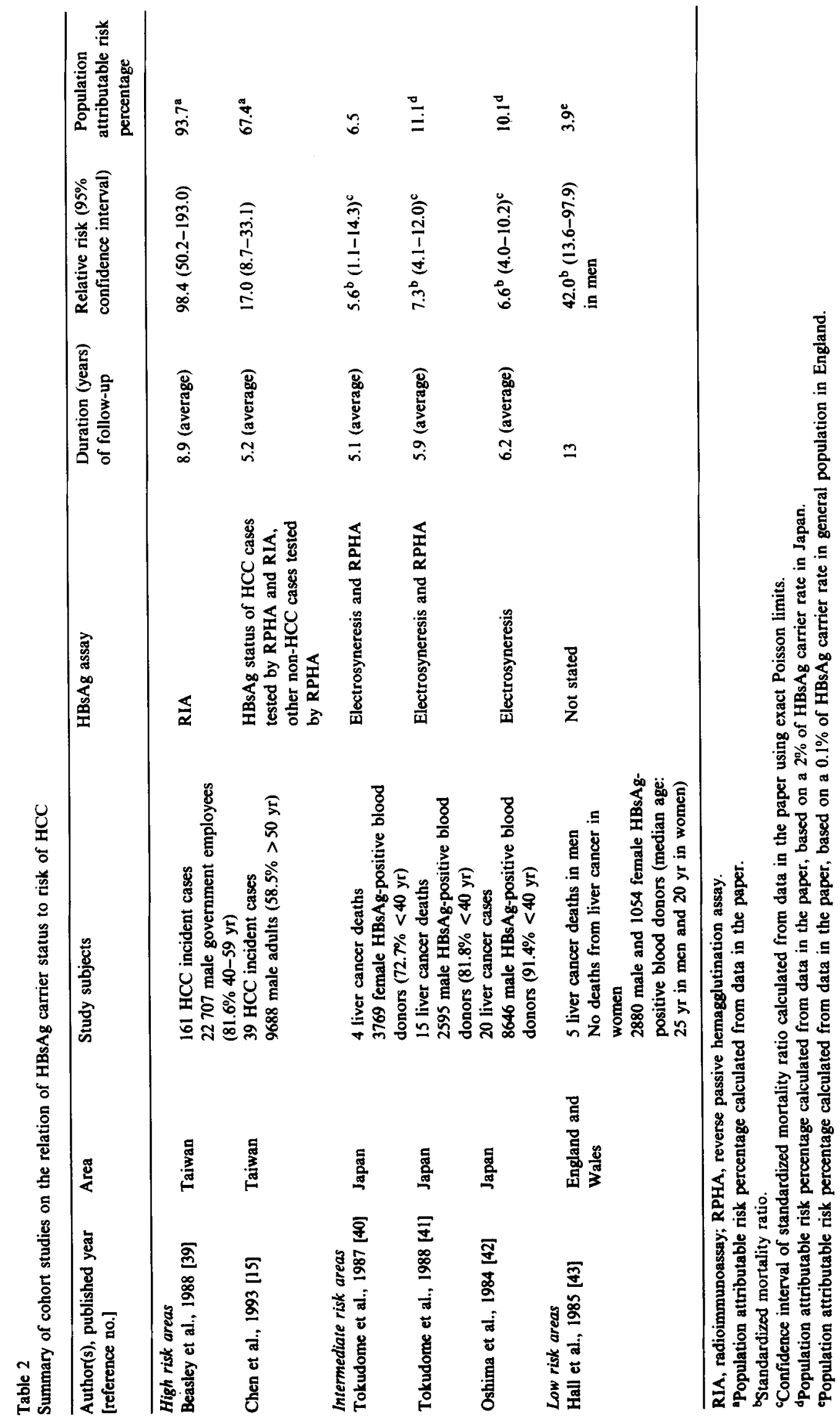




\subsection{Experimental studies}

3.2.1. Animal models. The development of HBVrelated HCC has been studied in many animal models. HBV belongs to the family of hepadnavirus which shows great genomic and biologic homologies but limited cross-infectivity [44]. In addition to HBV, three hepadnaviruses including woodchuck hepatitis virus (WHV) [45,46], ground squirrel hepatitis virus (GSHV) [47], and duck hepatitis B virus (DHBV) [48-50], have been found to cause persistent infection and a variety of liver diseases similar to $\mathrm{HBV}$ including acute and chronic hepatitis, characterized by hepatocyte necrosis, inflammatory reaction as well as liver regeneration, and HCC in infected animals. Animal studies with these hepadnaviruses have provided further insight into the relationship of chronic HBV infection to the development of HCC.

The original model, developed by Summers et al. in 1978, showed that persistent WHV infection was associated with a high incidence of HCC in captive woodchucks [45]. Popper et al. investigated the evolution of experimental WHV infection of woodchucks [46]. The most striking finding was that $\mathrm{HCC}$ developed within 3 years after infection in $100 \%(8 / 8)$ of experimentallyinfected chronic carriers of WHV surface antigen (6 infected at birth, 2 infected in adulthood) in the absence of an external co-carcinogen under well-controlled conditions. There was no HCC observed in laboratory animals having a past WHV infection without becoming carriers or in uninfected control animals.

In the study of GSHV-induced HCC, colonies of GSHV-infected and uninfected captive ground squirrels were followed for a five-year period [47]. HCC appeared in 2 of 28 GSHV carrier animals and 1 of 23 squirrels with past GSHV infection, while no HCC were observed in animals without serologic evidence of current carrier status or past GSHV infection. The relatively low incidence of HCC in carrier ground squirrels was in great contrast to the high HCC incidence observed in woodchucks chronically infected with WHV. This discrepancy was suspected to be due to viral and/or host susceptibility factors. A recent study compared the oncogenic potential of GSHV and WHV in woodchucks [51]. Despite the similarity in the replication of WHV and GSHV in experimentally-infected woodchucks, HCC developed in GSHV carriers about 18 months later than in WHV carriers. The frequency of HCC was also lower in GSHV-infected woodchucks than in WHV infected woodchucks. This observation implied that the discrepancy in the oncogenic potential between the two hepadnaviruses may depend on specific determinants in viral genomes.

Although the mammalian hepadnaviruses such as WHV and GSHV have been associated with the development of $\mathrm{HCC}$, the association of $\mathrm{DHBV}$ with $\mathrm{HCC}$ in ducks is less clear. HCC was reported in DHBVinfected ducks from a region of China where $\mathrm{HCC}$ is common in both ducks and humans [48]. However, HCC has not been observed in persistently DHBVinfected domestic ducks in the United States. There was no evidence for the induction of $\mathrm{HCC}$ in experiments with congenitally DHBV-infected ducks [49,50].

Besides the animal studies on hepadnavirus, evidence for the link between HBV and human HCC comes from experiments with transgenic mice carrying different $H B V$ genes. Chisari et al. constructed transgenic mice that overexpress the HBV large envelope polypeptide [52]. The dysregulation of the HBV protein causes its accumulation in hepatocytes and then severe, prolonged cellular injury that triggers a cascade of events including inflammation, regenerative hyperplasia, chromosomal aberrations, and eventually the development of HCC. Dunsford et al. conducted a study in which 59 transgenic mice that overproduced the HBV large envelope polypeptide and 9 age-sex-matched non-transgenic littermate controls were followed for evidence of $\mathrm{HCC}$ throughout their 24-month life span [53]. All the transgenic mice developed $\mathrm{HCC}$ at ages between 1 and 2 years, but no histopathological changes were observed in the non-transgenic controls over the same period of observation.

HBV may predispose individuals to liver carcinogenesis directly by its viral gene products. Kim et al. investigated the role of $X$ gene of $\mathrm{HBV}(\mathrm{HBx})$, which has been demonstrated to encode a protein acting as a transcriptional transactivator, in the pathogenesis of $\mathrm{HCC}$ in a $\mathrm{HBx}$ gene transgenic mouse model [54]. The high expression of $\mathrm{HBx}$ gene in the liver provoked progressive morphological changes beginning with multifoci of altered hepatocytes, followed by the appearance of benign adenomas, and proceeded to the development of HCC. HCC developed in most of the transgenic mice but in a relatively low percentage of controls.

A recent study also reported that a non-malignant fetal mouse hepatocyte cell line transfected with HBV DNA displayed malignant growth characteristics in soft agar and caused the formation of HCC upon inoculation in nude mice [55]. This result suggested that HBV genome has oncogenic potential.

In summary, most of the animal studies mentioned above have provided evidence for a role of $\mathrm{HBV}$ in the development of $\mathrm{HCC}$, except for the experiments with DHBV-infected ducks. Although these animal models have improved our understanding of the hepatocarcinogenic mechanisms induced by HBV, the earlier onset of $\mathrm{HCC}$ and the nearly $100 \%$ risk for the development of HCC in certain experimental animals are different from those observed in most human hepatomas. No external co-factors required in the pathogenesis of HCC in these animal models might also be different from $\mathrm{HBV}$-induced hepatocarcinogenesis in humans which usually needs a relatively long incubation period of several decades and multifactorial involvement.

3.2.2. Molecular studies. The integration of HBV into 
cellular DNA has been detected in approximately $90 \%$ of liver tissues from $\mathrm{HBsAg}$-positive $\mathrm{HCC}$ patients and many $\mathrm{HCC}$ cell lines [56-68]. The fact that the integrated sequences of $\mathrm{HBV}$ genome are also present in liver tissues of chronic HBV carriers and patients with HBV-related chronic liver diseases $[57,60,61,68]$ suggests the viral integration may occur during the longlasting period of chronic HBV infection.

Southern blot analyses of HBV DNA in HCC have shown that these tumors are clonal with respect to the integration pattern of HBV DNA [56-59]. This implied that the viral integration may proceed or accompany the transforming event in HCC induction. The possible roles of the integration of $\mathrm{HBV}$ into host genome at the initial stage of hepatocarcinogenesis have been intensively investigated.

Integration of HBV DNA into cellular genome may cause chromosomal alterations including deletions [69-71], translocations [72-74] and duplications [72,75-77]. The ability of HBV to induce chromosomal aberrations is consistent with its potential role as a tumor initiator. The loss of chromosome has been linked to the loss of functional tumor suppressor genes in many human cancers [78]. Deletion in chromosome 11p that contains the Wilm's tumor locus has been reported to be associated with a $\mathrm{HBV}$ integration site in $\mathrm{HCC}$ [69-71]. Although the deletion of chromosome 17p near the $p 53$ gene was frequently observed in HBV-integrated $\mathrm{HCC}$ in an area where high exposure to aflatoxins has been suspected of causing a high frequency of point mutations on p53 locus, especially in the 249 th codon, of HCC tissues [79], there was no direct evidence that the $17 \mathrm{p}$ deletions were associated with $\mathrm{HBV}$ integrations $[69,80]$. Chromosomal translocation may also be involved in the development of HCC. However, unlike the specific translocations observed in a variety of hematopoietic neoplasms [81], no common translocation was identified in HCC. Translocations between chromosomes 5:9, X:17 [72], 17:18 [73], and 17:7 [74] at the HBV integration site have been reported.

HBV may also act as an insertional mutagen by the integration of viral DNA into host genome and activating cellular proto-oncogenes in the flanking host DNA. The insertional activations of $\mathrm{N}-m y c$ or c-myc genes by WHV DNA integration have been reported in one third of HCCs in woodchucks [82]. These findings implied that WHV may contribute to the genesis of liver tumor, like non-acute retroviruses, through insertion of viral enhancer and disruption of normal proto-oncogene expression. However, this mechanism may not be operative in most HBV-related HCCs. In humans, nonspecific integration of HBV DNA into multiple cellular DNA sites in liver tumor tissues was frequently observed $[59,61,62,65,66,68]$. A study investigating a total of 14 paired human HCC and adjacent nontumorous tissues found no relationship between the acti- vation of ras and c-myc oncogenes in $\mathrm{HCC}$ and the expression of $H B V$ gene or the presence of viral DNA/RNA at the cellular level [83]. So far there have been very few documented $\mathrm{HCC}$ cases with $\mathrm{HBV}$ integration site within or near the cellular genes crucial for growth control and differentiation [84-88].

An alternative way for the integration of HBV DNA into host genome to be involved in the evolution of $\mathrm{HCC}$ is through the transactivation of cellular genes by gene products encoded by the integrated HBV DNA. The $\mathrm{X}$ protein translated from the $\mathrm{X}$ open reading frame of HBV genome has been known as a non-specific activator of transcription [89-98]. Most integrated HBV DNAs preserved the major part of its $X$ gene $[76,99]$. A large proportion of $\mathrm{HBV}$ carriers with $\mathrm{HCC}$ have been reported to be positive for the $\mathrm{X}$ antigen in their tumor cells [100]. Although the loss of $3^{\prime}$ end region of $X$ gene due to integration was frequently observed, many such truncated products retain transactivation activity [93]. Activations of a variety of cellular and viral genes by $X$ protein in vitro have also been demonstrated [89-98]. A recent study also suggested that the $X$ protein was a novel serine/threonine protein kinase [101]. As certain retroviral oncogenes known to encode protein kinase have been shown to induce transformation of cells in culture and oncogenesis in vivo [102,103], the $X$ gene may have the potential to alter cell growth and differentiation by catalyzing phosphorylation of cellular factors involved in the regulation of transcription. A fraction of HCC patients may not contain a functional $X$ gene [100]. The $H B V$ gene product translated from truncated pre S2/S sequences of integrated HBV DNAs has also been reported to have a transcriptional transactivation activity $[104,105]$. However, further studies are required to determine the percentage of HCCs which express a truncated pre $\mathbf{S} 2 / \mathrm{S}$ protein with a transcriptional transactivating activity and how important is the role of this protein in hepatocarcinogenesis.

3.2.3. Possible mechanisms of $H B V$-related hepatocarcinogenesis. Table 3 summarizes current views of the mechanisms through which HBV infection may cause the development of HCC. HBV may function as a tumor initiator through a non-specific mechanism to cause cellular DNA rearrangements $[72,75,77]$ or to augment expressions of cellular growth genes by the action of $X$ protein [89-98]. As chromosomal aberration is frequently observed in liver tumor tissues, the unstable nature of HBV integrated cellular DNA may be a common mechanism for the HBV-related hepatocarcinogenesis. However, the rearrangement of cellular DNA at HBV integration sites occurs not only in HCCs but also in HBV chronically-infected liver tissues [76]. The exact role played by the rearrangement of cellular gene in the development of HCC is unclear. Transactivation of cellular genes by the products of integrated HBV pre $\mathrm{S} 2 / \mathrm{S}$ or $X$ gene has been proposed to explain the connec- 
Table 3

Possible mechanisms of HBV-related hepatocarcinogenesis

\begin{tabular}{|c|c|}
\hline Mechanism² & Comment \\
\hline $\begin{array}{l}\text { Integration of HBV DNA into host hepatocyte may cause an unstable } \\
\text { structure of cellular DNA and therefore chromosomal aberrations } \\
{[72,75,77]} \\
\text { a. Induce chromosomal deletion } \\
\text { del } 11 p[70,71] \\
\text { b. Induce chromosomal translocation } \\
t(17,18)[73] \mathrm{t}(17,7)[74] \\
t(5,9)[72] \mathrm{t}(\mathrm{X}, 17)[72]\end{array}$ & $\begin{array}{l}\text { Chromosomal aberrations are frequently observed in human } \\
\text { HCCs. Rearrangement of cellular DNA at HBV DNA inte- } \\
\text { gration sites is non-specific for HCCs [76]. Specific chromo- } \\
\text { somal aberrations associated with all HBV-related HCCs } \\
\text { have not been yet found. }\end{array}$ \\
\hline $\begin{array}{l}\text { HBV X [89-98] and pre } S 2 / S(104,105) \text { gene products have a } \\
\text { transcriptional trans-activating function. Integration of } \mathrm{HBV} X \text { or } \\
\text { pre } S 2 / \mathrm{S} \text { gene sequence may cause inappropriate expressions of } \\
\text { cellular genes. }\end{array}$ & No evidence supports this hypothesis in human. \\
\hline $\begin{array}{l}\text { Site-specific integration of HBV DNA into host genome may directly } \\
\text { activate cellular oncogenes and/or inactivate tumor suppressor } \\
\text { genes. }\end{array}$ & \\
\hline $\begin{array}{l}\text { a. HBV DNA integrates within or closely to cellular genes critical for } \\
\text { growth control } \\
\text { Retinoic acid receptor gene }[84,85] \text { cyclin A gene [86] p53 gene [87] }\end{array}$ & $\begin{array}{l}\text { Site-specific integration of HBV DNA in human HCCs is } \\
\text { very infrequent and may not readily explain the majority of } \\
\text { HBV-associated HCCs. }\end{array}$ \\
\hline $\begin{array}{l}\text { b. Cause overexpression of cellular oncogenes } \\
\text { hst-1 gene [88] C-myc gene (woodchuck model) }[107,108] \mathrm{N}-m y c \\
\text { gene (woodchuck model) [82] }\end{array}$ & $\begin{array}{l}\text { Overexpression of known oncogenes has not been observed } \\
\text { as a common phenomenon of HBV-related HCCs in human } \\
{[83,109] \text {. }}\end{array}$ \\
\hline $\begin{array}{l}\text { Persistent HBV infection can cause prolonged hepatocellular injury } \\
\text { characterized by chronic phasic necroinflammation and then induce } \\
\text { regenerative hyperplasia of hepatocyte and eventually the malignant } \\
\text { transformation }[46,52,53,110] \text {. }\end{array}$ & $\begin{array}{l}\text { Chronic hepatitis and liver cirrhosis are common sequence } \\
\text { of chronic HBV infection. Over } 85 \% \text { of } \mathrm{HBV} \text {-related HCCs } \\
\text { have cirrhosis [111]. An elevated risk of HCC has also been } \\
\text { observed in alcoholics and patients with hemochromatosis or } \\
\alpha_{1} \text {-antitrypsin deficiency. }\end{array}$ \\
\hline
\end{tabular}

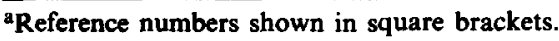

tion between non-specific integration of HBV DNA and HCC development $[89-98,104,105]$. The findings from the HBx gene transgenic mouse model [54] and several in vitro studies [89-98] suggest that the expression of the HBV $X$ gene in hepatocytes may contribute, at least partly, to the development of HCC. However, which cellular genes that are involved in the pathogenesis of human HCC may be activated by $X$ gene remain to be determined. No evidence for a specific cellular integration site of HBV DNA has been reported to date [106]. In addition, there were only a limited number of documented HCC cases reported to have HBV insertions within or next to cellular genes associated with cell growth control and differentiation program [84-88]. This indicated that the insertional mutation accounts for a tiny fraction of human HCCs.

HCC usually develops after 20-30 years of persistent $\mathrm{HBV}$ infection accompanied by the signs of hepatocyte necrosis, inflammation, and regenerative hyperplasia in chronic HBV carriers. Chronic hepatitis and liver cirrhosis have long been suggested to be important endogenous factors in the development of HCC. This implies that the main mechanism for $\mathrm{HBV}$ to predispose individuals to HCC may be through the hepatic injury and non-specific regenerative proliferation, rather than a direct genetic event. The continuous hepatocyte regeneration may allow an accumulation of multiple mutational events and provide a growth stimulation to a rare cell that already has a genetic change due to random mutation or the integration of HBV genome. The fact that there is a much higher risk for developing HCC among chronic HBV carriers than individuals with past HBV infection is consistent with this explanation and argues against the importance of the hit-and-run mechanism by insertional mutation in the HBV-induced hepatocarcinogenesis. The WHV animal model has emphasized the role of necroinflammation in the development of HCC $[46,110]$. The findings from the HBV envelope transgenic mouse model provide important evidence for the molecular mechanism of hepatic injury responsible for $\mathrm{HCC}$ induction [52,53]. Indeed, no changes in known oncogenes and tumor suppressor genes were observed during hepatocarcinogenesis in the transgenic mouse model [112]. Although the pathogenesis of hepatic injury in HBV-related liver diseases may be mediated by both virological factors and host immune system rather than by the dysregulation of the HBV envelop protein [113], the HBV transgenic mouse may provide a good model for the investigation of the association between the chronic hepatic damage and continuous liver regeneration and the development of HCC. 


\section{HCV and HCC}

\subsection{Non-A, non-B hepatitis and HCC}

The application of sensitive immunological assay in the 1970s for testing and differentiating infections with hepatitis $A$ and $B$ viruses led to the identification of a distinct type of infectious hepatitis, namely non-A, non$B$ hepatitis, which was negative on serological markers of known hepatotropic viruses such as hepatitis A virus, hepatitis B virus, cytomegalovirus, and Epstein-Barr virus. Non- $A$, non-B hepatitis has been shown to be the most common serious consequence of blood transfusion; it accounts for approximately $85-95 \%$ of posttransfusion hepatitis cases. It has been reported that $7-10 \%$ of transfused patients were affected with non-A, non-B hepatitis [114].

The link between non-A, non-B post-transfusion hepatitis and HCC was proposed according to clinical observations. A long-term follow-up study indicated that a large proportion of cases of acute non-A, non-B transfusion-associated hepatitis developed chronic hepatitis defined by an elevated level of alanine aminotransferase (ALT) for more than 6 months [115]. These patients may have a persistently abnormal liver function manifested at least by an increased ALT level for several years or go on to develop an asymptomatic carrier state. A substantial fraction of these patients has been reported to progress to liver cirrhosis $[114,115]$. Several cases who developed HCC subsequent to chronic posttransfusion hepatitis have also been reported [5-8].

In addition to clinical observations, the evidence for the association between non- $A$, non- $B$ hepatitis and HCC was from pathological studies. Liver cell dysplasia has been observed in $42.5 \%$ of the liver biopsy and surgical resection specimens from patients with various forms of non-A, non-B hepatitis including acute hepatitis, chronic hepatitis and cirrhosis [116]. This finding suggests that liver cell dysplasia and HCC may be the sequelae of non-A, non-B hepatitis.

The importance of non-A, non-B transfusionassociated hepatitis in the development of $\mathrm{HCC}$ was emphasized by the studies on the recent increasing trend of HCC incidence in Japan $[26,117]$. Although the incidence of HCC for men in Japan increased steadily between 1958 and 1983, the number of HCC cases positive for $\mathrm{HBsAg}$ remained almost unchanged during this period. The increasing HCC incidence has been hypothesized to be associated with non-A, non-B hepatitis on the basis of the fact that an increasing number of patients with cirrhosis and $\mathrm{HCC}$ who had a past history of blood transfusion but no serological markers of HBV were observed by many Japanese physicians [26]. The increased proportion of HCC cases unrelated to HBV has been confirmed by a later study on the analyses of HBV DNA in livers of HCC cases [1.17].

Although non-A, non-B post-transfusion hepatitis has long been suspected of playing a role in the development of HCC, the association of the non-A, non-B hepatitis with $\mathrm{HCC}$ could be investigated only recently after the isolation of a blood-borne non-A, non-B hepatitis viral genome, designated hepatitis $C$ virus (HCV), by using a recombinant complementary DNA approach. A specific assay for circulating $\mathrm{HCV}$ antibody has been developed [9]. Using this immunoassay anti-HCV has been detected in more than $80 \%$ of patients with chronic post-transfusion non-A, non-B hepatitis from Italy and Japan $[10,118,119]$. In the United States, anti-HCV has also been associated with most community-acquired non-A, non-B hepatitis with no identifiable source of parenteral exposure to $\mathrm{HCV}$ [10].

\subsection{Anti-HCV in patients with chronic liver diseases or $\mathrm{HCC}$}

The prevalence of anti-HCV in patients with various chronic liver diseases has been intensively investigated (Table 4). Anti-HCV was detected in about $1 \%$ of blood donors [111,121,124,129-131]. In patients with chronic liver diseases or $\mathrm{HCC}$, the percentages of anti-HCV positivity were $4-58 \%$ in $\mathrm{HBsAg}$-positive cases and 43-90\% in HBsAg-negative cases. The anti-HCV prevalence was consistently higher in HBsAg-negative than in HBsAg-positive patients with chronic liver diseases or HCC. The most striking discrepancy in the prevalence between $\mathrm{HBsAg}$-positive and $\mathrm{HBsAg}$-negative cases was observed in Japan. A high frequency of anti-HCV positivity was also observed in patients with alcoholic liver diseases. Among HCC cases, the HCC patients with cirrhosis had a higher prevalence of anti-HCV than those without coexisting cirrhosis.

The high prevalence of anti-HCV in patients with chronic liver diseases or HCC, particularly in the HBsAg-negative patients, in contrast to the relatively low anti-HCV prevalence in blood donors in different areas of different $\mathrm{HCC}$ incidence, suggests the $\mathrm{HCV}$ infection may play a role in the development of $\mathrm{HCC}$ throughout the world. However, these case-series studies can not be used to estimate a valid relative risk associated with HCC development for anti-HCV positivity due to the lack of appropriate comparison group.

\subsection{Epidemiological studies on the association of $\mathrm{HCV}$ with $\mathrm{HCC}$}

Several case-control studies have provided information on the relation between HCV infection and HCC. In most of the case-control studies as summarized in Table 5, a significant association between anti-HCV positivity and $\mathrm{HCC}$ was observed with a relative risk ranging 6-62. Only one study conducted in Thailand failed to show an increased risk of developing HCC among individuals positive for anti-HCV. However, the prevalence of anti-HCV among $\mathrm{HCC}$ cases $(6.3 \%)$ in this 
Table 4

Frequency of antibody to hepatitis $\mathrm{C}$ virus in patients with $\mathrm{HCC}$ and chronic liver diseases

\begin{tabular}{|c|c|c|c|c|}
\hline $\begin{array}{l}\text { Author(s), } \\
\text { published year } \\
\text { [reference no.] }\end{array}$ & Area & Study subjects & $\begin{array}{l}\text { Anti-HCV } \\
\text { assay }\end{array}$ & Positive rate of anti-HCV \\
\hline $\begin{array}{l}\text { High risk areas } \\
\text { Chen et al., } 1990 \\
{[111]}\end{array}$ & Taiwan & $\begin{array}{l}78 \mathrm{HBs} \text { Ag-positive chronic hepatitis cases } \\
43 \mathrm{HBsAg} \text {-negative chronic hepatitis cases } \\
31 \mathrm{HBsA} \text {-positive cirrhosis cases } \\
30 \mathrm{HBsAg} \text {-negative cirrhosis cases } \\
42 \mathrm{HBsAg} \text {-positive } \mathrm{HCC} \text { cases } \\
24 \mathrm{HBsAg-negative} \mathrm{HCC} \mathrm{cases} \\
420 \text { blood donors }\end{array}$ & RIA & $\begin{array}{l}\text { HBsAg-positive chronic hepatitis: } 7.7 \% \\
\text { HBsAg-negative chronic hepatitis: } 65.0 \% \\
\text { HBsAg-positive cirrhosis: } 10.0 \% \\
\text { HBsAg-negative cirrhosis: } 43.0 \% \\
\text { HBsAg-positive HCC: } 17.0 \% \\
\text { HBsAg-negative HCC: } 63.0 \% \\
\text { Blood donors: } 0.95 \%\end{array}$ \\
\hline $\begin{array}{l}\text { Intermediate risk arec } \\
\text { Bruix et al., } 1989 \\
{[120]}\end{array}$ & Spain & $\begin{array}{l}96 \text { HCC cases } \\
106 \text { liver cirrhosis cases } \\
177 \text { patients admitted for various surgical } \\
\text { procedures unrelated to liver disease as } \\
\text { controls }\end{array}$ & EIA & $\begin{array}{l}\text { HCC: } 75 \% \\
\text { HCC without cirrhosis: } 0 \% \\
\text { HBsAg-positive HCC with cirrhosis: } \\
55.5 \% \\
\text { HCC with alcoholic cirrhosis: } 76.6 \% \\
\text { HCC with cryptogenic cirrhosis: } 81.4 \% \\
\text { Liver cirrhosis: } 55.6 \% \\
\text { Controls: } 7.3 \%\end{array}$ \\
\hline $\begin{array}{l}\text { Vargas et al., } 1990 \\
\quad[121]\end{array}$ & Spain & $\begin{array}{l}81 \mathrm{HCC} \text { cases } \\
33 \text { alcoholic liver cirrhosis cases } \\
2915 \text { blood donors (HBsAg status not stated) }\end{array}$ & EIA & $\begin{array}{l}\text { HCC: } 54 \% \\
\text { Alcoholic liver cirrhosis: } 24 \% \\
\text { Blood donors: } 1 \%\end{array}$ \\
\hline $\begin{array}{c}\text { Colombo et al., } \\
1989 \text { [122] }\end{array}$ & Italy & $\begin{array}{l}41 \text { HBsAg-positive HCC cases } \\
91 \text { HBsAg-negative HCC cases } \\
139 \text { chronic liver disease cases }\end{array}$ & RIA & $\begin{array}{l}\text { HBsAg-positive HCC: } 54 \% \\
\text { HBsAg-negative HCC: } 70 \% \\
\text { Chronic liver disease: } \mathbf{7 4} \%\end{array}$ \\
\hline $\begin{array}{l}\text { Levrero et al., } 1991 \\
\text { [118] }\end{array}$ & Italy & $\begin{array}{l}53 \text { HBsAg-positive HCC cases } \\
114 \text { HBsAg-negative HCC cases } \\
50 \text { non-A, non-B chronic post-transfusion } \\
\text { hepatitis cases } \\
50 \text { cryptogenic chronic hepatitis cases }\end{array}$ & EIA & $\begin{array}{l}\text { HBsAg-positive HCC: } 28.3 \% \\
\text { HBsAg-negative HCC: } 71.9 \% \\
\text { Non-A, non-B chronic post-transfusion } \\
\text { hepatitis: } 94.0 \% \\
\text { Cryptogenic chronic hepatitis: } 82.0 \%\end{array}$ \\
\hline $\begin{array}{l}\text { Simonetti et al., } \\
1989 \text { [123] }\end{array}$ & Italy & $\begin{array}{l}200 \mathrm{HCC} \text { cases }(\text { cirrhosis }=180, \text { without } \\
\text { cirrhosis }=15, \mathrm{HBsAg} \text {-positive }=31, \mathrm{HBsAg}- \\
\text { negative }=169 \text { ) }\end{array}$ & EIA & $\begin{array}{l}\text { Total HCC: } 76 \% \\
\text { HCC with cirrhosis: } 78 \% \\
\text { HCC without cirrhosis: } 40 \% \\
\text { HBsAg-positive HCC: } 58 \% \\
\text { HBsAg-negative HCC: } 79 \%\end{array}$ \\
\hline $\begin{array}{l}\text { Watanabe et al., } \\
1991 \text { [124] }\end{array}$ & Japan & $\begin{array}{l}23 \mathrm{HBsAg-positive} \mathrm{HCC} \text { cases } \\
102 \mathrm{HBsAg} \text {-negative } \mathrm{HCC} \text { cases } \\
56 \text { patients with other cancers } \\
100 \text { blood donors negative for } \mathrm{HBsAg} \text { and } \\
\text { anti-HCV c100 and with normal ALT }\end{array}$ & $\begin{array}{l}\text { Anti-p } 22 \\
\text { tested by } \\
\text { Western blot, } \\
\text { Anti-C100 } \\
\text { tested by } \\
\text { EIA }\end{array}$ & $\begin{array}{l}\text { Anti-p22 } \\
\text { HBsAg-positive HCC:4.3\% } \\
\text { HBsAg-negative HCC:83.3\% } \\
\text { Other cancers: } 12.5 \% \\
\text { Blood donors: } 1.0 \% \\
\text { Anti-C100 } \\
\text { HBsAg-negative HCC: } 66.7 \%\end{array}$ \\
\hline $\begin{array}{l}\text { Nishioka et al., } \\
1991[125]\end{array}$ & Japan & $\begin{array}{l}75 \mathrm{HBsAg} \text {-positive } \mathrm{HCC} \text { cases } \\
105 \mathrm{HBsAg} \text {-negative } \mathrm{HCC} \text { cascs }\end{array}$ & EIA & $\begin{array}{l}\text { HBsAg-positive HCC: } 14.7 \% \\
\text { HBsAg-negative HCC: } 76.2 \%\end{array}$ \\
\hline $\begin{array}{c}\text { Kiyosawa et al., } \\
1990 \text { [119] }\end{array}$ & Japan & $\begin{array}{l}50 \mathrm{HBsAg-positive} \mathrm{chronic} \mathrm{hepatitis} \mathrm{cases} \\
96 \text { non-A, non-B chronic hepatitis cases } \\
46 \mathrm{HBsAg-positive} \mathrm{cirrhosis} \mathrm{cases} \\
81 \text { non-A, non-B chronic hepatitis-related } \\
\text { cirrhosis cases } \\
29 \mathrm{HBsAg-positive} \mathrm{HCC} \mathrm{cases} \\
54 \text { non-A, non-B chronic hepatitis-related } \\
\text { HCC cases }\end{array}$ & EIA & $\begin{array}{l}\text { HBsAg-positive chronic hepatitis: } 6 \% \\
\text { Non-A, non-B chronic hepatitis: } 89.6 \% \\
\text { HBsAg-positive cirrhosis: } 17.4 \% \\
\text { Non-A, non-B chronic hepatitis-related } \\
\text { cirrhosis: } 86.4 \% \\
\text { HBsAg-positive HCC: } 34.5 \% \\
\text { Non-A, non-B chronic hepatitis-related } \\
\text { HCC: } 94.4 \%\end{array}$ \\
\hline $\begin{array}{l}\text { Saito et al., } 1990 \\
\text { [126] }\end{array}$ & Japan & $\begin{array}{l}51 \text { HBsAg-positive HCC cases } \\
202 \mathrm{HBsAg} \text {-negative } \mathrm{HCC} \text { cases } \\
148 \mathrm{HBsAg} \text {-negative patients with other }\end{array}$ & RIA & $\begin{array}{l}\text { HBsAg-positive HCC: } 3.9 \% \\
\text { HBsAg-negative HCC: } 66.3 \% \\
\text { Other cancers: } 10.1 \%\end{array}$ \\
\hline
\end{tabular}


Table 4 (Continued)

\begin{tabular}{|c|c|c|c|c|}
\hline $\begin{array}{l}\text { Author(s), } \\
\text { published year } \\
\text { [reference no.] }\end{array}$ & Area & Study subjects & $\begin{array}{l}\text { Anti-HCV } \\
\text { assay }\end{array}$ & Positive rate of anti-HCV \\
\hline \multicolumn{5}{|l|}{ Low risk areas } \\
\hline $\begin{array}{l}\text { Nalpas et al., } 1991 \\
\text { [127] }\end{array}$ & France & $\begin{array}{l}55 \text { Patients with } \mathrm{HCC} \text { and cirrhosis } \\
78 \text { alcoholic cirrhosis cases } \\
96 \text { non-cirrhotic alcoholic liver disease cases } \\
\text { (HBsAg status not stated) }\end{array}$ & EIA & $\begin{array}{l}\text { HCC: } 58.2 \% \\
\text { Alcoholic cirrhosis: } 35.9 \% \\
\text { Non-cirrhotic alcoholic liver disease: } \\
17.7 \%\end{array}$ \\
\hline $\begin{array}{l}\text { Hasan et al., } 1990 \\
\text { [128] }\end{array}$ & $\begin{array}{l}\text { United } \\
\text { States }\end{array}$ & $\begin{array}{l}28 \mathrm{HBs} A \mathrm{~g} \text {-positive } \mathrm{HCC} \text { cases } \\
59 \mathrm{HBs} \mathrm{Ag}_{\text {-negative } \mathrm{HCC} \text { cases (HCC patients }} \\
\text { who consumed more than } 80 \mathrm{~g} \text { alcohol daily } \\
\text { for }>10 \text { years or those affected with herno- } \\
\text { chromatosis or autoimmune hepatitis or } \\
\text { primary biliary cirrhosis or } \alpha_{1} \text {-antitrypsin } \\
\text { deficiency were excluded) } \\
76 \text { cryptogenic cirrhosis cases } \\
200 \text { blood donors }\end{array}$ & RIA & $\begin{array}{l}\text { HBsAg-positive HCC: } 14 \% \\
\text { HBsAg-negative HCC: } 53 \% \\
\text { Cryptogenic cirrhosis: } 42 \% \\
\text { Blood donors: } 0.5 \%\end{array}$ \\
\hline
\end{tabular}

RIA, radioimmunoassay; EIA, enzyme immunoassay; ALT, alanine transferase.

study was low. The fraction of HCC attributable to $\mathrm{HCV}$ in terms of population attributable risk percentage varied from 9 to $29 \%$ in high HCC risk areas, 12 to $60 \%$ in intermediate risk areas, and less than $30 \%$ in the United States. Although the development of more sensitive assays to determine the presence of HCV markers may change these proportions in the future, $\mathrm{HCV}$ appears to be a more important cause of HCC than HBV in Japan. However, HBV is the more important etiological factor in the Far East and Africa.

The consistency of the association of anti-HCV positivity with $\mathrm{HCC}$ and the high relative risk among individuals positive for anti-HCV in several case-control studies suggests HCV may have a role in the etiology of HCC. However, these case-control studies examined the anti-HCV status of HCC patients and controls at the time the subjects were recruited. In other words, the anti-HCV status of $\mathrm{HCC}$ patients was tested after their diseases were diagnosed. The temporal relationship between $\mathrm{HCV}$ infection and the development of $\mathrm{HCC}$ cannot therefore be justified by these case-control studies. Prospective study is needed to provide unequivocal evidence that $\mathrm{HCV}$ infection precedes the development of HCC.

There has been only one nested case-control study using the stored sera from a community-based prospective study of liver cancer in Taiwan to investigate the association between anti-HCV status and the development of HCC to date [17]. After adjusting for other $\mathrm{HCC}$ risk factors such as HBsAg carrier status, habits of cigarette smoking and alcohol drinking, history of dietary consumption frequency, as well as past history of liver diseases, the relative risk of $\mathrm{HCC}$ associated with anti-HCV was 37.0 with a $95 \%$ CI ranging from 4.6 to 295.2. Although this study may provide the most per- suasive evidence for the hypothesis that $\mathrm{HCV}$ is involved in the pathogenesis of $\mathrm{HCC}$, it is unclear whether the association between anti-HCV positivity and HCC observed in Taiwan applies to other countries.

\subsection{Comparison and implication of anti-HCV assays}

The status of anti-HCV was determined by assays for antibodies to non-structural $\mathrm{HCV}$ protein c100 in most studies mentioned above. These first-generation assays have been shown to have the limitation of insensitivity and non-specificity. A fraction of chronic non-A, non-B hepatitis patients whose sera were negative for antiHCV by the first-generation RIA were reported to have substantial levels of HCV RNA in their livers [139]. Watanabe et al. used Western blot analysis to investigate the prevalence of antibodies to $\mathrm{HCV}$ core protein (anti-p22) in a series of HBsAg-negative HCC patients and compared this assay with tests for detecting anti-C100. Among 102 serum samples from HCC patients, 85 $(83.3 \%)$ were positive for anti-p22, whereas $68(66.7 \%)$ of the same 102 cases were positive for the anti-C-100 by ELISA [124]. The relatively lower sensitivity of the firstgeneration EIAs compared to the second-generation immunoassays, which include polypeptides derived from non-structural and structural regions of $\mathrm{HCV}$ genome, has also been reported recently [140].

The non-specificity of the anti-HCV immunoassays based on $\mathrm{cl} 00$ has been demonstrated by several lines of observations $[141,142]$. False positivity was reported among patients with autoimmune chronic active hepatitis who had hyperglobulinemia [141]. As patients with other chronic liver diseases may also have a high serum level of globulin and most HCC patients have coexisting chronic liver diseases, similar false-positive results may be obtained in patients with HCC and thus lead to a sec- 


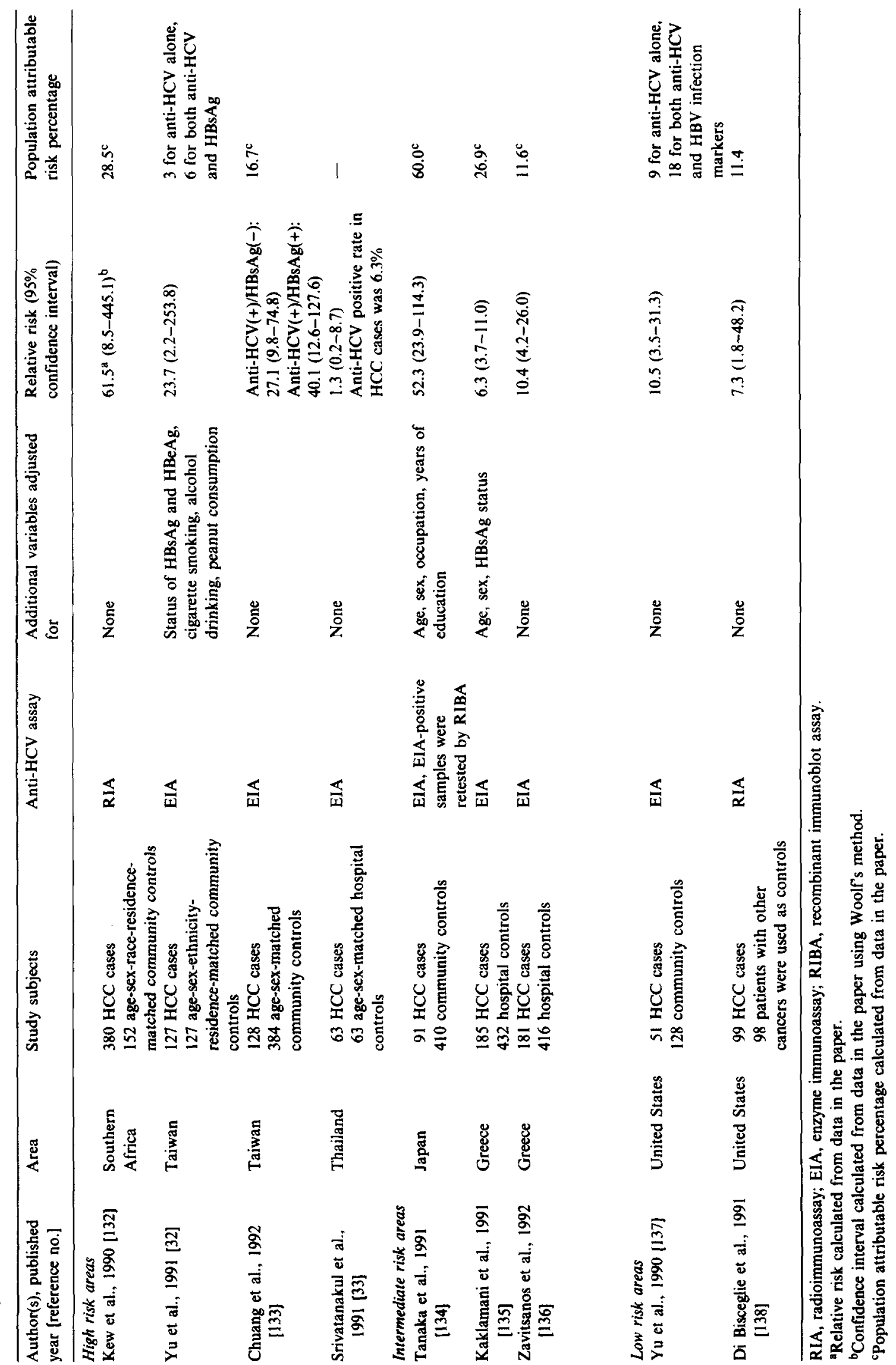


ondary association between anti-HCV positivity and HCC. However, only a weak correlation was observed between the absorbance value in the Ortho ELISA test and serum globulin concentration among patients with HCC in a recent study [134]. This implies that the much higher prevalence of anti-HCV in HCC cases than in controls may not simply be due to hyperglobulinemia. Non-specific reactivity may also arise from prolonged storage of frozen serum samples [142]. However, this may only bias the relative risk of developing $\mathrm{HCC}$ associated with anti-HCV status toward the null if the duration of serum storage prior to testing were the same for cases and controls.

The exact meaning of a positive test for anti-HCV is not completely understood. The prevalence of anti-HCV was extremely high in patients with chronic posttransfusion non-A, non-B hepatitis, but it was much lower in those with acute resolving post-transfusion non-A, non-B hepatitis [10]. In a follow-up study of transfusion recipients affected with acute and chronic non-A, non-B hepatitis, anti-HCV persisted in the circulation of most patients affected with chronic hepatitis. But the patients affected with acute resolving hepatitis did not proceed to anti-HCV positivity after a certain period of follow-up [143]. Blood donors who were positive for anti-HCV usually had no symptoms or signs of liver disease. These persons may also have persistent $\mathrm{HCV}$ infection in analogy to the asymptomatic carriers of HBV. It would be of interest to assess the subsequent clinical course of these symptom-free carriers of $\mathrm{HCV}$. Alberti et al. studied liver biopsy samples from individuals who had been anti-HCV positive for more than 6 months but had no symptoms or signs of liver disease [144]. Out of 23 patients, $16(70 \%)$ were found to have histological evidence of chronic hepatitis which could not be predicted by serum ALT, but was wellcorrelated with HCV-RNA in serum. These findings have challenged the hypothesis regarding the existence of 'true' healthy carriers of $\mathrm{HCV}$.

$\mathrm{HCV}$ is a virus containing a positive-stranded RNA genome [145]. The oncogenic potential of $\mathrm{HCV}$ is unclear so far. According to currently available data, $\mathrm{HCV}$ does not integrate into the host genome like HBV [145]. Insertional mutation is therefore unlikely to be a mechanism responsible for $\mathrm{HCV}$-related hepatocarcinogenesis. HCV infection has been shown to be strongly associated with chronic liver disease and cirrhosis. This suggests that the hepatocarcinogenesis of $\mathrm{HCV}$ may be a process from unresolved viral hepatitis, chronic hepatitis, liver cirrhosis to HCC. However, HCV infection may also be associated with $\mathrm{HCCs}$ without cirrhosis [123]. The mechanism through which HCV may directly contribute to the development of $\mathrm{HCC}$ requires further investigation. The heterogeneity of $\mathrm{HCV}$ genome has been demonstrated [145]. Although different HCV strains have been found in Japan and the United States, whether the different viral strains may play a different role in the pathogenesis of $\mathrm{HCC}$ remains unclear.

\section{Interactions of $\mathrm{HBV}$ or $\mathrm{HCV}$ with other risk factors in the etiology of $\mathrm{HCC}$}

\subsection{Joint effect of $\mathrm{HBV}$ and $\mathrm{HCV}$}

Interactive effects between $\mathrm{HBV}$ and $\mathrm{HCV}$ in the development of $\mathrm{HCC}$ were recently postulated by several authors on the basis of case-series and case-control studies. Colombo et al. investigated the prevalence of anti$\mathrm{HCV}$ in Italian patients with $\mathrm{HCC}$ and chronic liver diseases [122]. The co-occurrence of anti-HCV and anti$\mathrm{HBc}$ was observed in 49 of $91(54 \%) \mathrm{HBsAg}$-negative HCC patients, but only in 26 of $139(19 \%)$ patients with non-A, non-B chronic liver disease. This result implies that infection with both HBV and HCV may cause a more serious liver disease than infection with only one single agent. In a case-control study on the possible association between $\mathrm{HCV}$ infection and $\mathrm{HCC}$ in the United States including $51 \mathrm{HCC}$ patients ( 12 black and 39 white) and 128 controls ( 1 black and 127 white), a synergistic effect of HBV markers and anti-HCV on the HCC risk was observed [137]. In a case-control study involving $185 \mathrm{HCC}$ cases and 432 hospital controls in Greece, the relative $\mathrm{HCC}$ risk associated with anti-HCV positivity was substantially higher among $\mathrm{HBsAg}$ carriers than among non-carriers (relative risk $=20.0$ vs. 4.8) [135]. Two studies conducted in Taiwan also reported a significant interaction between anti-HCV and HBsAg [32,133]. In our previous case-control study, 9 HCC cases out of 127 were positive for anti-HCV and HBsAg but none of the 127 matched-controls were observed to be positive for both viral markers [32]. The other case-control study in Taiwan found that the relative risk of developing $\mathrm{HCC}$ was 14.0 for carriers of $\mathrm{HBsAg}$ alone, 27.1 for individuals with anti-HCV positivity alone, and $\mathbf{4 0 . 1}$ for those who were positive for both HBsAg and anti-HCV [133]. The prevalence of anti-HCV was about $1 \%$ in the general population, $3.5 \%$ in prostitutes and more than $80 \%$ in hemophiliacs and parenteral drug abusers in Taiwan [111]. As most HBsAg carriers are infected in early childhood in Taiwan [3], it seems unlikely that the co-occurrence of HBsAg and anti-HCV among HCC patients is due to common transmission routes. It is therfore reasonable to speculate that HCV superinfection in HBsAg carriers may synergistically increase the risk of developing $\mathrm{HCC}$.

It has been shown that HCV superinfection suppresses HBV replication in patients with chronic hepatitis B. However, chronic hepatitis B patients with anti-HCV were more likely to have severe liver disease than those without anti-HCV [146]. The mechanism of the interaction between $\mathrm{HCV}$ and $\mathrm{HBV}$ in the pathogenesis of HCC merits further scrutiny. 


\subsection{Joint effect of $H B V$ and aflatoxins}

Aflatoxins, especially aflatoxin $\mathrm{B}_{1}\left(\mathrm{AFB}_{1}\right)$ which is the most abundant and potent naturally occurring form, are well-established hepatic carcinogens in many animal species $[147,148]$. Heavy aflatoxin contaminations of food have been reported in tropical Africa and southeastern Asia where carrier rate of $\mathrm{HBV}$ is also high. The interaction between aflatoxin exposure and chronic $\mathrm{HBV}$ infection has long been suspected to play an important role in the induction of $\mathrm{HCC}$ in these areas.

Four ecological correlation studies have assessed the relationship among aflatoxin exposure, chronic HBV infection, and the incidence of HCC [149-152]. In a study carried out in Swaziland, the level of aflatoxin intake was measured in dietary samples from representative households across four broad geographic regions. Aflatoxin exposure was found to be a more important determinant of HCC than HBsAg carrier status [149]. In a study including eight districts of different HCC incidence and ethnic groups in Kenya [150], the aflatoxin exposure measured by urinary excretion of $\mathrm{AFB}_{1}$ guanine adducts was found to be moderately correlated with HCC incidence in an ethnic group. There was no synergistic effect of chronic HBV infection and aflatoxin exposure on the risk of HCC. In southern Guangxi of China, where the annual mortality rate of liver cancer was as high as 120 per 100000 population, it was observed that the variation in HCC mortality rate across communities was strongly correlated with the local level of aflatoxin exposure measured by the regular collection and testing of staple foods [151]. However, there was little association between prevalence of $\mathrm{HBsAg}$ positivity and liver cancer mortality in these communities. In contrast, no association between HCC mortality and aflatoxin exposure was observed in a study in $\mathbf{4 8}$ counties of China. There was a wide range of aflatoxin exposure, $\mathrm{HBsAg}$ carrier rate, and $\mathrm{HCC}$ mortality rates in these study areas. The HCC mortality was not associated with the aflatoxin exposure indexed by aflatoxin metabolites in pooled urine samples, but it was positively correlated with the HBsAg carrier rate [152]. However, no details on the time of urine collection were stated.

Ecological correlation study evaluates the association between exposure and disease based on data collected at the population level. As the contamination level of aflatoxin in foodstuffs of a given population does not necessarily reflect the exposure to aflatoxin at the individual level, several methods for measuring urinary aflatoxin metabolites and $\mathrm{AFB}_{1}$-albumin adducts have been applied to quantitate individual $\mathbf{A F B}_{1}$ exposure $[153,154]$. In a recent nested case-control study using urinary concentration of $\mathrm{AFB}_{1}$ metabolites as a biomarker of aflatoxin exposure in Shanghai in Chind, a strong interaction between chronic $\mathrm{HBV}$ infection and aflatoxin exposure was observed [16]. For individuals who were chronic HBV carriers and had a detectable level of urinary aflatoxin metabolites, the relative risk of developing HCC was 12.5-times higher than those who had chronic HBV infection alone.

The synergistic interaction between $\mathrm{HBV}$ and aflatoxin in hepatocarcinogenesis has also been studied in duck and transgenic mouse models. In a Pekin duck model, the incidence of liver tumors (including adenoma and HCC) was higher in ducks infected at birth with DHBV and treated with a dose of $0.08 \mathrm{mg} / \mathrm{kg}$ body weight of $\mathrm{AFB}_{1}(3 / 6)$ than in the DHBV-uninfected ducks treated with the same dose of $\mathrm{AFB}_{1}(3 / 10)$. However, no liver tumors were observed in 13 DHBVinfected ducks treated with a lower dose $(0.02 \mathrm{mg} / \mathrm{kg}$ body weight) of $\mathrm{AFB}_{1}$, while 2 of $10 \mathrm{DHBV}$-uninfected ducks treated with the lower dose of $\mathrm{AFB}_{1}$ had developed liver tumors [49]. The other Pekin duck model conducted by Cullen et al. showed that the daily administration of aflatoxin for 60 days induced HCCs in 4 of 8 newly hatched Pekin ducks congenitally infected with HBV. HCCs were also observed in 3 of 4 DHBVuninfected ducks neonatally exposed to aflatoxin [50]. Thus the findings in these duck models did not support an interaction between DHBV and aflatoxin exposure.

In a transgenic mouse model, exposure of female HBsAg transgenic mice to aflatoxin caused more rapid development of premalignant changes and more adenomas and HCCs than in the transgenic mice not exposed to the carcinogen [155].

$\mathrm{AFB}_{1}$ can bind covalently with cellular DNA $[156,157]$. It may act as an initiator or a promoter through causing mutations of proto-oncogenes $[158,159]$ or tumor suppressor genes $[79,160]$ which play crucial roles in the pathogenesis of HCC. However, numerous findings from in vitro and in vivo studies suggested that the mammalian liver may be relatively resistent to chemical carcinogenesis in the mitotically inactive situation [161]. A majority of HCCs were also observed to occur in cirrhotic livers [111]. It is therefore reasonable to speculate that regenerative hyperplasia stimulated by chronic HBV infection may have an important role in the aflatoxin-induced hepatocarcinogenesis.

Enhancement of metabolic activation of $\mathrm{AFB}_{1}$ by $\mathrm{HBV}$ infection may be an alternative mechanism for the interaction of $\mathbf{A F B}_{1}$ with $\mathbf{H B V}$. $\mathbf{A F B}_{1}$ was activated much more efficiently by liver preparations from WHVcarriers than by those from uninfected animals [162]. A significant enhancement of the $\mathrm{AFB}_{1}$ activation was also observed in human biopsies from $\mathrm{HBsAg}$ carriers with mild chronic active hepatitis [163]. However, this finding was observed on a limited number of human liver tissues. No association of the presence of $\mathrm{AFB}_{1-}$ DNA adducts with either the integration of HBV DNA [164] or the expression of HBV antigens [165] was observed in liver tissues of $\mathrm{HCC}$ cases. 


\subsection{Interaction of $\mathrm{HBV}$ with alcohol drinking or cigarette smoking}

There was some evidence for interaction of chronic HBV infection with alcohol drinking or cigarette smoking in the development of HCC. In a nested case-control study involving $20 \mathrm{HCC}$ cases identified from a cohort study of 8646 male voluntary blood donors who were found to be HBsAg-positive and 40 age-sex-matched controls selected from the cohort in Japan, a strong dose-response relationship between alcohol drinking and HCC was observed after adjusting for the habit of cigarette smoking. A much higher risk of HCC among heavy smokers was also observed when compared with carriers of HBsAg without a habit of cigarette smoking after adjusting for alcohol drinking [42].

In our previous case-control study of 200 male HCC cases and 200 age-sex-ethnic group-residence-matched community controls in Taiwan, an additive synergism of HBV carrier status with alcohol drinking and cigarette smoking was observed [11]. Habitual alcohol drinking (defined as drinking alcohol more than 3 days per week for more than 15 years) and cigarette smoking were associated with a three- to five-times increase in risk of HCC among chronic HBV carriers. However, no adjustment was made for the effect of one risk factor when the relative risk for the interaction between the other risk factor and HBV carrier status was estimated.

\subsection{Interaction of $\mathrm{HCV}$ with alcohol drinking, cigarette smoking and hepatitis $D$ virus}

There have been relatively few investigations on the interactive effects between $\mathrm{HCV}$ infection and other risk factors in the etiology of HCC. A high frequency of anti$\mathrm{HCV}$ has been reported among patients with alcoholic liver cirrhosis and patients with alcoholic cirrhosis com- bined with $\mathrm{HCC}[120,121,127]$. This suggests that HCV infection may be involved in the development of liver cirrhosis and $\mathrm{HCC}$ in some patients with alcoholinduced liver disease. A synergistic effect on $\mathrm{HCC}$ development between anti-HCV positivity and habitual alcohol drinking was also observed in our previous casecontrol study in Taiwan [32]. However, no adjustment was made for cigarette smoking and HBsAg status.

The evidence for the interaction between HCV infection and cigarette smoking in the etiology of HCC was from two case-control studies [32,166]. A case-control study conducted in Greece reported the relative risk for developing $\mathrm{HCC}$ in relation to anti-HCV positivity after controlling for age, sex, and HBsAg status was $6.8(95 \%$ $\mathrm{CI}=3.6-13.0)$ among smokers but only $3.2(95 \%$ $\mathrm{CI}=1.0-10.2$ ) among non-smokers [166]. In our previous case-control study, the relative risk of $\mathrm{HCC}$ was $1.5(95 \% \mathrm{CI}=0.8-2.6)$ among cigarette smokers who were negative for anti-HCV, 5.6.(95\% $\mathrm{CI}=0.5-286.4)$ for non-smokers who were positive for anti-HCV, and as high as $13.9(95 \% \mathrm{CI}=1.8-630.9)$ for cigarette smokers who were anti-HCV positive, as compare with nonsmokers who were anti-HCV negative [32]. However, alcohol drinking and HBsAg status were not taken into account when these relative risks were calculated.

Cigarette smoke contains many chemical carcinogens associated with tumor initiation and promotion. As liver is the major site for the metabolism of external chemicals, it may also be a target for the action of these carcinogens. A moderate excess risk of HCC among cigarette smokers has been demonstrated in several previous studies $[11,13-15]$. The mechanism underlying the synergistic effect between anti-HCV positivity and cigarette smoking remains to be studied.

Possible interactive effect between $\mathrm{HCV}$ and hepatitis

Table 6

Summary of associations of $\mathrm{HCC}$ risk with $\mathrm{HBV}$ or HCV/non-A, non-B post-transfusion hepatitis by different study designs

\begin{tabular}{|c|c|c|}
\hline Study design & HBV $^{\mathbf{a}}$ & HCV/non-A, non-B hepatitis \\
\hline Ecological & $\begin{array}{l}\text { Positive association internationally }[21] \text { and } \\
\text { intranationally }[3,22] \text {. }\end{array}$ & \\
\hline Migrant & Chinese migrating to Singapore and the United & \\
\hline Case-control & $\begin{array}{l}\text { States retain a high risk of developing } \mathrm{HCC}[20] \text {. } \\
\text { Strong positive association; relative risk associated } \\
\text { with } \mathrm{HBsAg} \text { status ranging } 5-20(11,27-38) \text {. }\end{array}$ & $\begin{array}{l}\text { Most studies suggested strong positive association } \\
\text { with a relative risk of anti-HCV positivity ranging } \\
6-62[32,132-138] \text {. One study in Thailand reported } \\
\text { no association [33]. }\end{array}$ \\
\hline Cohort & $\begin{array}{l}\text { Strong positive association; the relative risk associ- } \\
\text { ated with } \mathrm{HBsAg} \text { status ranged } 6-100[15,39-43] \text {. }\end{array}$ & $\begin{array}{l}\text { Only one nested case-control study has shown posi- } \\
\text { tive association [17]. }\end{array}$ \\
\hline Clinical/experimental & $\begin{array}{l}\text { Hepadna viruses share certain important features } \\
\text { with retroviruses in molecular structure and repli- } \\
\text { cation mechanism [167]. HBV DNA integrates } \\
\text { into host genome [56-68]. HBV X and pre S2/S } \\
\text { gene products have a transactivation function } \\
\text { [89-98,104,105]. Hepadna viruses can induce HCC } \\
\text { in animal models }[46,47] \text {. HBV transgenic mice } \\
\text { have a much higher risk of HCC than non- } \\
\text { transgenic mice }(53,54) \text {. }\end{array}$ & $\begin{array}{l}\text { Several cases develop HCC after non-A, non-B post- } \\
\text { transfusion hepatitis [ } 5-8 \text { ]. Liver cell dysplasia is } \\
\text { associated with non-A, non-B hepatitis [116]. A high } \\
\text { frequency of antibody to HCV was detected in } \\
\text { patients with various chronic liver diseases [111, } \\
118-128 \text { ]. A case of HCC was reported in a chim- } \\
\text { panzee } 7 \text { years after inoculation with human plasma } \\
\text { from a patient with non-A, non-B hepatitis [168]. }\end{array}$ \\
\hline
\end{tabular}

${ }^{a}$ Reference numbers shown in square brackets. 
D virus (HDV) in the etiology of $\mathrm{HCC}$ has been investigated in only one case-control study [166]. No evidence of synergistic effect between anti-HCV and anti-HDV was found in this study. However, there were only $9 \mathrm{HCC}$ cases positive for anti-HDV.

\section{Conclusions}

The associations of $\mathrm{HCC}$ with $\mathrm{HBV}$ and $\mathrm{HCV} /$ non-A, non-B hepatitis in different study designs are summarized in Table 6. As can be seen, the association between $\mathrm{HBV}$ and HCC is strong and consistent, and has been demonstrated using various study designs. However, the evidence for the association between $\mathrm{HCV}$ infection and $\mathrm{HCC}$ is limited to the findings from case-series and casecontrol studies. Only one nested case-control study conducted in a limited area and one animal study based on a follow-up of a limited number of chimpanzees have investigated the role of $\mathrm{HCV}$ in the causation of HCC. Therefore, efforts should be made to carry out further prospective studies on various populations and develop additional animal models for the study of HCV-related hepatocarcinogenesis. On the other hand, there has been considerable evidence suggesting that $\mathrm{HCC}$ is multifactorial in origin. Either HBV or HCV may not be a sufficient cause for the development of HCC. However, only very few studies have been conducted to assess the HCC risk associated with joint exposures to $\mathrm{HBV}$ or $\mathrm{HCV}$ and to other major risk factors of HCC, especially aflatoxins. The interactive effects between these viruses and other risk factors in most previous studies were not adequately explored either. Further studies aimed at the investigation of these interactive effects may improve our understanding of the multifactorial etiology of HCC.

\section{Reviewer}

This paper was reviewed by David Milich, Ph.D., Department of Molecular Biology, Scripps Research Institute, La Jolla, CA 92037 USA.

\section{References}

1 Wold WSM, Green M. Historic milestones in cancer virology. Semin Oncol 6:461-477, 1979.

2 Zur Hausen H. Viruses in human cancers. Science 254: 1167-1173, 1991.

3 Beasley RP. Hepatitis B virus as the etiologic agent in hepatocellular carcinoma: epidemiologic considerations. Hepatology 2 (Suppl.):21s-26s, 1982.

4 Tabor F. Hepatocellular carcinoma: possible etiologies in patients without serological evidence of hepatitis $B$ virus infection. $J$ Med Virol 27:1-6, 1989.

5 Resnick RH, Stone K, Antonioli D. Primary hepatocellular carcinoma following non-A, non-B post-transfusion hepatitis. Digest Dis Sci 28:908-911, 1983.

6 Gilliam JH, Geisinger KR, Richter JE. Primary hepatocellular carcinoma after chronic non-A, non-B post-transfusion hepatitis. Ann Intern Med 101:794-795, 1984.
7 Kenichi K, Hideo H, Akira I et al. The correlation of non-A, non-B hepatitis virus with hepatocellular carcinoma [Abstract]. Hepatology 157:2, 1982.

8 Ayoola EA, Odelola HA, Johnson AOK. Primary liver cancer (PLC) after non-A, non-B hepatitis (NANBH) [Abstract]. Hepatology 154:2, 1982.

9 Choo QL, Kuo G, Weiner AJ et al. Isolation of a cDNA clone derived from a blood-borne non-A, non-B viral hepatitis genome. Science 244:359-362, 1989.

$10 \mathrm{Kuo} \mathrm{G}$, Choo QL, Alter HJ et al. An assay for circulating antibodies to a major etiologic virus of human non-A, non-B hepatitis. Science 244:362-364, 1989.

11 Chen CJ, Liang KY, Chang AS et al. Effects of hepatitis B virus, alcohol drinking, cigarette smoking and familial tendency on hepatocellular carcinoma. Hepatology 13:398-406, 1991

12 International Agency for Research on Cancer. IARC Monographs on the Evaluation of Carcinogenic Risks to Humans, Vol. 44: Alcohol Drinking. Lyon, France: International Agency for Research on Cancer, 1988; 207-215.

13 Yu MC, Mack T, Hanisch R et al. Hepatitis, alcohol consumption, cigarette smoking, and hepatocellular carcinoma in Los Angeles. Cancer Res 43:6077-6079, 1983.

14 Hirayama TA. A large-scale cohort study on risk factors for primary liver cancer, with special reference to the role of cigarette smoking. Cancer Chemother Pharmacol 23 (Suppl.): sl14-s117, 1989.

15 Chen CJ, Yu MW, Wang CJ et al. Multiple risk factors of hepatocellular carcinoma: a cohort study of 13737 male adults in Taiwan. J Gastroenterol Hepatol 8 (Suppl.): s83-s87, 1993.

16 Ross RK, Yuan JM, Yu MC et al. Urinary aflatoxin biomarkers and risk of hepatocellular carcinoma. Lancet 339:943-946, 1992.

$17 \mathrm{Yu} \mathrm{MW}$, Chen CJ. Elevated serum testosterone levels and risk of hepatocellular carcinoma. Cancer Res 53:790-794, 1993.

18 Van Rensburg SJ, Cook-Mozaffari P, Van Schalkwyk DJ et al. Hepatocellular carcinoma and dietary aflatoxin in Mozambique and Transkei. Br J Cancer 51:713-726, 1985.

19 Anonymous. Hepatocellular cancer: differences between high and low incidence regions. Lancet ii:1183-1184, 1987.

$20 \mathrm{Yu}$ MW, Tsai SF, Hsu KH et al. Epidemiologic characteristics of malignant neoplasms in Taiwan: II. Liver cancer. J Natl Public Health Assoc (ROC) 8:125-138, 1988.

21 Szmuness W. Hepatocellular carcinoma and the hepatitis B virus: evidence for a causal association. Prog Med Virol 24: 40-69, 1978.

22 Chen CJ, Chang YC, Tsai SF et al. Epidemiological studies of multiple risk factors in hepatocellular carcinoma in Taiwan. In: Zuckerman AJ, eds. Viral Hepatitis and Liver Disease. New York: Alan R. Liss, 1988; 723-725.

23 Saracci R, Repetto F. Time trends of primary liver cancer: in dication of increased incidence in selected cancer registry populations. J Natl Cancer Inst 65:241-247, 1980.

24 Shanmugaratnam K, Lee HP, Day NE. Cancer Incidence in Singapore. Lyon, France: International Agency for Research on Cancer, 1978.

25 Ho LH, Chan CL, Lau WH et al. Cancer in Hong Kong: some epidemiological observations. Natl Cancer Inst Monogr $62: 47-55,1982$.

26 Okuda K, Fujimoto I, Hanai A, Urano Y. Changing incidence of hepatocellular carcinoma in Japan. Cancer Res 47: 4967-4972, 1987.

27 Prince AM, Szmuness W, Michon J, Demaille J. A case/control study of the association between primary liver cancer and hepatitis B infection in Senegal. Int J Cancer 16: 376-383, 1975.

28 Lingao AL, Domingo EO, Nishioka K. Hepatitis B virus profile of hepatocellular carcinoma in the Philippines. Cancer 48:1590-1595, 1981.

29 Lam KC, Yu MC, Leung JW, Henderson BE. Hepatitis B virus 
and cigarette smoking: risk factors for hepatocellular carcinoma in Hong Kong. Cancer Res 42:5246-5248, 1982.

30 Yeh FS, Mo CC, Luo S, Henderson BF, Tong MJ, Yu MC. A serological case-control study of primary hepatocellular carcinoma in Guangxi, China. Cancer Res 45:872-873, 1985.

31 Lu SN, Lin TM, Chen CJ et al. A case-control study of primary hepatocellular carcinoma in Taiwan. Cancer 62: 2051-2055, 1988.

32 Yu MW, You SL, Chang AS et al. Association between hepatitis $\mathbf{C}$ virus antibodies and hepatocellular carcinoma in Taiwan. Cancer Res 51:5621-5625, 1991.

33 Srivatanakul P, Parkin DM, Khlat $M$ et al. Liver cancer in Thailand: II. A case-control study of hepatocellular carcinoma. Int J Cancer 48:329-332, 1991.

34 Tsukuma H, Hiyama T, Oshima A et al. A case-control study of hepatocellular carcinoma in Osaka, Japan. Int $\mathrm{J}$ Cancer 45:231-236, 1990.

35 Trichopoulos D, Day NE, Kaklamani E et al. Hepatitis B virus, tobacco smoking and ethanol consumption in the etjology of hepatocellular carcinoma. Int J Cancer 39: 45-49, 1987.

36 Mayans MV, Calvet X, Bruix J et al. Risk factors for hepatocellular carcinoma in Catalonia, Spain. Int J Cancer 46:378-381, 1990.

37 Yarrish RL, Werner BC, Blumberg BS. Association of hepatitis B virus infection with hepatocellular carcinoma in American patients. Int J Cancer 26:711-715, 1980.

38 Austin H, Delzell E, Grufferman S et al. A case-control study of hepatocellular carcinoma and hepatitis B virus, cigarette smoking, and alcohol consumption. Cancer Res 46:962-966, 1986.

39 Beasley RP. Hepatitis B virus: the major etiology of hepatocellular carcinoma. Cancer 61:1942-1956, 1988.

40 Tokudome S, Ikeda M, Matsushita K et al. Hepatocellular carcinoma among female Japanese hepatitis B virus carriers. Hepatogastroenterology 34:246-248, 1987.

41 Tokudome S, Ikeda M, Matsushita K et al. Hepatocellular carcinoma among $\mathrm{HBsAg}$ positive blood donors in Fukuoka, Japan. Eur J Cancer Clin Oncol 24:235-239, 1988.

42 Oshima A, Tsukuma H, Hiyama $T$ et al. Follow-up study of HBsAg-positive blood donors with special reference to effect of drinking and smoking on development of liver cancer. Int $\mathbf{J}$ Cancer 34:775-779, 1984.

43 Hall AJ, Winter PD, Wright R. Mortality of hepatitis B positive blood donors in England and Wales. Lancet i:91-93, 1985.

44 Summers J. Three recently described animal virus models for human hepatitis B virus. Hepatology 1:179-183, 1981.

45 Summers J, Smolec JM, Snyder R. A virus similar to human hepatitis B virus associated with hepatitis and hepatoma in woodchucks. Proc Natl Acad Sci USA 75:4533-4537, 1978.

46 Popper H, Roth L, Purcell RH et al. Hepatocarcinogenicity of the woodchuck hepatitis virus. Proc Natl Acad Sci USA 84:866-870, 1987.

47 Marion PL, Van Davelaar MJ, Knight SS et al. Hepatocellular carcinoma in ground squirrels persistently infected with ground squirrel hepatitis virus. Proc Natl Acad Sci USA 83:4543-4546, 1986.

48 Omata M, Uchiumi K, Ito $Y$ et al. Duck hepatitis B virus and liver diseases. Gastroenterology 85: 260-267, 1983.

49 Cova $L$, Wild CP, Mehrotra $R$ et al. Contribution of aflatoxin Bl and hepatitis B virus infection in the induction of liver tumors in ducks. Cancer Res 50:2156-2163, 1990.

50 Cullen JM, Marion PL, Sherman GJ et al. Hepatic neoplasms in aflatoxin Bl-treated, congenital duck hepatitis B virusinfected, and virus-free Pekin ducks. Cancer Res 50: 4072-4080, 1990.
51 Seeger C, Baldwin B, Hornbuckle WE et al. Woodchuck hepatitis virus is a more efficient oncogenic agent than ground squirrel hepatitis virus in a common host. J Virol 65:1673-1679, 1991.

52 Chisari FV, Klopchin K, Moriyama T et al. Molecular pathogenesis of hepatocellular carcinoma in hepatitis B virus transgenic mice. Cell 59:1145-1156, 1989.

53 Dunsford HA, Sell S, Chisari FV. Hepatocarcinogenesis due to chronic liver cell injury in hepatitis $B$ virus transgenic mice. Cancer Res 50:3400-3407, 1990.

$54 \mathrm{Kim} \mathrm{CM}$, Koike K, Saito I et al. HBx gene of hepatitis B virus induces liver cancer in transgenic mice. Nature 351:317-320, 1991.

55 Hohne M, Schaefer S, Seifer $M$ et al. Malignant transformation of immortalized transgenic hepatocytes after transfection with hepatitis B virus DNA. EMBO J 9:1137-1145, 1990.

56 Bréchot C, Pourcel C, Louise A, Rain B, Tiollais P. Presence of integrated hepatitis B virus DNA sequences in cellular DNA of human hepatocellular carcinoma. Nature 286:533-535, 1980.

57 Shafritz DA, Shouval D, Sherman HI, Hadziyannis SJ, Kew MC. Integration of hepatitis B virus DNA into the genome of liver cells in chronic liver disease and hepatocellular carcinoma. Studies in percutaneous liver biopsies and post-mortem tissue specimens. N Engl J Med 305:1067-1073, 1981.

58 Br'echot C, Hadchouel M, Scotto J et al. State of hepatitis B virus DNA in hepatocytes of patients with hepatitis B surface antigen-positive and -negative liver diseases. Proc Natl Acad Sci USA 78:3906-3910, 1981.

59 Shafritz DA, Kew MC. Identification of integrated hepatitis B virus DNA sequences in human hepatocellular carcinomas. Hepatology 1:1-8, 1981.

60 Shafritz DA. Integration of HBV-DNA into liver and hepatocellular carcinoma cells during persistent $\mathrm{HBV}$ infection. J Cell Biochem 20:303-316, 1982.

61 Miller RH, Lee SC, Liaw YF, Robinson WS. Hepatitis B viral DNA in infected human liver and in hepatocellular carcinoma. J Infect Dis 151:1081-1092, 1985.

62 Chen JY, Harrison TJ, Lee CS et al. Detection of hepatitis B virus DNA in hepatocellular carcinoma. $\mathrm{Br} \mathrm{J}$ Exp Pathol 67:279-288, 1986.

63 Lai MY, Chen DS, Chen PJ et al. Status of hepatitis B virus DNA in hepatocellular carcinoma: a study based on paired tumor and nontumor liver tissues. J Med Virol 25:249-258, 1988.

64 Chang MH, Chen PJ, Chen JY et al. Hepatitis B virus integration in hepatitis B virus-related hepatocellular carcinoma in childhood. Hepatology 13:316-320, 1991.

65 Zhou YZ, Butel JS, Li PJ et al. Integrated state of subgenomic fragments of hepatitis B virus DNA in hepatocellular carcinoma from mainland China. J Natl Cancer Inst 79:223-231, 1987.

66 Hino O, Kitagawa T, Koike $\mathrm{K}$ et al. Detection of hepatitis B virus DNA in hepatocellular carcinomas in Japan. Hepatology 4:90-95, 1984.

67 Imazeki F, Omata M, Yokosuka O, Okuda K. Integration of hepatitis B virus DNA in hepatocellular carcinoma. Cancer 58: 1055-1060, 1986.

68 Yaginuma $H$, Kobayashi $H$, Kobayashi $M$ et al. Multiple integration site of hepatitis B virus DNA in hepatocellular carcinoma and chronic active hepatitis tissues from children. $J$ Virol 61:1808-1813, 1987.

69 Slagle BL, Zhou YZ, Butel JS. Hepatitis B virus integration event in human chromosome $17 \mathrm{p}$ near the $\mathrm{p} 53$ gene identifies the region of the chromosome commonly deleted in virus-positive hepatocellular carcinoma. Cancer Res 51:49-54, 1991.

70 Rogler CE, Sherman M, Su CY et al. Deletion in chromosome 
$11 \mathrm{p}$ associated with a hepatitis B integration site in hepatocellular carcinoma. Science 230:319-322, 1985.

71 Fisher JH, Scoggin CH, Rogler CE. Sequences which flank an $11 \mathrm{p}$ deletion observed in an hepatocellular carcinoma map to 11p13. Hum Genet 75:66-69, 1987.

72 Tokino T, Fukushige S, Nakamura $T$ et al. Chromosomal translocation and inverted duplication associated with integrated hepatitis B virus in hepatocellular carcinoma. J Virol 61:3848-3854, 1987.

73 Hino O, Shows TB, Rogler CE. Hepatitis B virus integration site in hepatocellular carcinoma at chromosome 17;18 translocation. Proc Natl Acad Sci USA 83:8338-8342, 1986.

74 Meyer M, Wiedorn KH, Hofschneider PH et al. A chromosome 17:7 translocation is associated with a hepatitis B virus DNA integration in human hepatocellular carcinoma DNA. Hepatology 15:665-671, 1992.

75 Ogata N, Tokino T, Kamimura T, Asakura H. A comparison of the molecular structure of integrated hepatitis B virus genomes in hepatocellular carcinoma cells and hepatocytes derived from the same patient. Hepatology 11:1017-1023, 1990.

76 Takada S, Gotoh Y, Hayashi S et al. Structural rearrangement of integrated hepatitis B virus DNA as well as cellular flanking DNA is present in chronically infected hepatic tissues. J Virol 64:822-828, 1990.

77 Yaginuma K, Kobayashi M, Yowshida E, Koike K. Hepatitis B virus integration in hepatocellular carcinoma DNA: duplication of cellular flanking sequences at the integration site. Proc Natl Acad Sci USA 82:458-462, 1985.

78 Weinberg RA. Tumor suppressor genes. Science 254: 1138-1146, 1991.

79 Hsu IC, Metcalf RA, Sun T et al. Mutational hotspot in the p53 gene in human hepatocellular carcinomas. Nature (London) 350:427-428, 1991.

80 Scorsone KA, Zhou YZ, Butel JS, Slagle BL. p53 mutations cluster at codon 249 in hepatitis B virus-positive hepatocellular carcinomas from China. Cancer Res 52:1635-1638, 1992.

81 Croce CM. Role of chromosome translocations in human neoplasia. Cell 49:155-156, 1987.

82 Fourel G, Trepo C, Bougueleret $L$ et al. Frequent activation of $\mathrm{N}-m y c$ genes by hepadna virus insertion in woodchuck liver tumors. Nature 347:294-298, 1990.

83 Lee HS, Rajagopalan MS, Vyas GN. A lack of direct role of hepatitis $B$ virus in the activation of ras and c-myc oncogenes in human hepatocellular carcinogenesis. Hepatology 8:1116-1120, 1988.

84 Benbrook D, Lernhardt E, Pfahl M. A new retinoic acid receptor identified from a hepatocellular carcinoma. Nature 333: 669-672, 1988.

85 Dejean A, de The H. Hepatitis B virus as an insertional mutagen in a human hepatocellular carcinoma. Mol Biol Mcd 7:213-222, 1990.

86 Wang J, Chenivesse X, Henglein B, Bréchot C. Hepatitis B virus integration in a cyclin $A$ gene in a hepatocellular carcinoma. Nature 343:555-557, 1990.

87 Zhou YZ, Slagle BL, Donehower LA et al. Structural analysis of a hepatitis B virus genome integrated into chromosome 17p of a human hepatocellular carcinoma. J Virol 62:4224-4231, 1988.

88 Hatada I, Tokino T, Ochiya T, Matsubara K. Co-amplification of integrated hepatitis B virus DNA and transforming gene $h s t-1$ in a hepatocellular carcinoma. Oncogene 3:537-540, 1988.

89 Seto E, Yen TS, Peterlin BM, Ou JH. Trans-activation of the human immunodeficiency virus long terminal repeat by the hepatitis B virus X protein. Proc Natl Acad Sci USA 85:8286-8290, 1988.
90 Spandau DF, Lee CH. Trans-activation of viral enhancers by the hepatitis B virus $X$ protein. J Virol 62: 427-434, 1988.

91 Twu JS, Schloemer RH. Transcriptional trans-activating function of hepatitis B virus. J Virol 61:3448-3453, 1987.

92 Wollersheim M, Debelka U, Hofschneider PH. A transactivating function encoded in the hepatitis $B$ virus $\mathbf{X}$ gene is conserved in the integrated state. Oncogene 3:545-552, 1988.

93 Takada S, Koike K. Trans-activation function of a $3^{\prime}$ truncated $X$ gene-cell fusion product from integrated hepatitis $B$ virus DNA in chronic hepatitis tissues. Proc Natl Acad Sci USA 87:5628-5632, 1990.

94 Hu KQ, Vierling JM, Siddiqui A. Trans-activation of HLA-DR gene by hepatitis B virus X gene product. Proc Natl Acad Sci USA 87:7140-7144, 1990.

95 Colgrove R, Simon G, Ganem D. Transcriptional activation of homologous and heterologous genes by the hepatitis $B$ virus $\mathrm{X}$ gene product in cell permissive for viral replication. J Virol 63:4019-4026, 1989.

96 Twu JS, Chu K, Robinson WS. Hepatitis B virus $X$ gene activates kappa B-like enhancer sequences in the long terminal repeat of immunodeficiency virus 1. Proc Natl Acad Sci USA 86:5168-5172, 1989.

97 Twu JS, Robinson WS. Hepatitis B virus X gene can transactivate heterologous viral sequences. Proc Natl Acad Sci USA 86:2046-2050, 1989.

98 Koike K, Shirakata Y, Yaginuma $K$ et al. Oncogenic potential of hepatitis B virus. Mol Biol Med 6:151-160, 1989.

99 Koike K, Kobayashi M, Yaginuma K, Shirakata Y. Structure and function of integrated HBV DNA. In: Robinson WS, Koike K, Will H, eds. Hepadna Viruses. New York: Alan R. Liss. 1987; 267-286.

100 Wang W, London WT, Feitelson MA. Hepatitis B $x$ antigen in hepatitis B virus carrier patients with liver cancer. Cancer Res 51:4971-4977, 1991.

101 Wu JY, Zhou ZY, Judd A et al. The hepatitis B virus-encoded transcriptional trans-activator hbx appears to be novel protein serine/threonine kinase. Cell 63:687-695, 1990.

102 Hanks SK, Quinn AM, Hunter T. The protein kinase family: conserved features and deduced phylogeny of the catalytic domains. Science 241:42-52, 1988.

103 Edelman AM, Blumenthal DK, Krebs EG. Protein serine/threonine kinases. Annu Rev Biochem 56:567-613, 1987.

104 Kekule AS, Lauer $U$, Meyer $M$ et al. The preS2/S region of integrated hepatitis B virus DNA encodes a transcriptional transactivator. Nature 343:457-461, 1990.

105 Caselmann WH, Meyer M, Kekule AS et al. A trans-activator function is generated by integration of hepatitis B virus preS/S sequences in human hepatocellular carcinoma DNA. Proc Natl Acad Sci USA 87:2970-2974, 1990.

106 Tokino T, Matsubara K. Chromosomal sites for hepatitis B virus integration in human hepatocellular carcinoma. $\mathrm{J}$ Virol 65: 6761-6764, 1991.

107 Hsu TY, Moroy T, Etiemble $J$ et al. Activation of c-myc by woodchuck hepatitis virus insertion in hepatocellular carcinoma. Cell 55:627-635, 1988.

108 Moroy T, Marchio A, Etiemble $J$ et al. Rearrangement and enhanced express of c-myc in hepatocellular carcinoma of hepatitis virus infected woodchucks. Nature 324:276-279, 1986.

109 Takada S, Koike K. Activated N-ras gene was found in human hepatoma tissue but only in a small fraction of the tumor cells. Oncogene 4:189-193, 1989.

110 Popper H, Shafritz DA, Hoofnagle JH. Relation of the hepatitis B virus carrier state to hepatocellular carcinoma. Hepatology 7:764-772, 1987

111 Chen DS, Kuo GC, Sung JL et al. Hepatitis C virus infection in 
an area hyperendemic for hepatitis $B$ and chronic liver disease: the Taiwan experience. J Infect Dis 162: 817-822, 1990.

112 Pasquinelli C, Bhavani K, Chisari FV. Multiple oncogenes and tumor suppressor genes are structurally and functionally intact during hepatocarcinogenesis in hepatitis B virus transgenic mice. Cancer Res 52:2823-2829, 1992.

113 Roingeard P, Romet-Lemonne JL, Leturcq D, Goudeau A, Essex M. Hepatitis B virus core antigen ( $\mathrm{HBcAg}$ ) accumulation in an HBV nonproducer clone of HepG2-transfected cells is associated with cytopathic effect. Virology 179:113-120, 1990.

114 Dienstag JL. Non-A, non-B hepatitis. I. Recognition, epidemiology, and clinical features. Gastroenterology 85:439-462, 1983.

115 Koretz RL, Stone O, Mousa M, Gitnick GL. Non-A, non-B post-transfusion hepatitis - a decade ago. Gastroenterology 88:1251-1254, 1985.

116 Lefkowitch JH, Apfelbaum TF. Liver cell dysplasia and hepatocellular carcinoma in non-A, non-B hepatitis. Arch Pathol Lab Med 111:170-173, 1987.

117 Sakamoto $\mathbf{M}$, Hirohashi $\mathrm{S}$, Tsuda $\mathbf{H}$ et al. Increasing incidence of hepatocellular carcinoma possibly associated with non-A, non-B hepatitis in Japan, disclosed by hepatitis B virus DNA analysis of surgically resected cases. Cancer Res 48:7294-7297, 1988.

118 Levrero M, Tagger A, Balsano $\mathrm{C}$ et al. Antibodies to hepatitis $\mathrm{C}$ virus in patients with hepatocellular carcinoma. J Hepatol 12:60-63, 1991

119 Kiyosawa K, Sodeyama T, Tanaka E et al. Interrelationship of blood transfusion, non-A, non-B hepatitis and hepatocellular carcinoma: analysis by detection of antibody to hepatitis $\mathrm{C}$ virus. Hepatology 12:671-675, 1990.

120 Bruix J, Barrera JM, Calvet X et al. Prevalence of antibodies to hepatitis $C$ virus in Spanish patients with hepatocellular carcinoma and hepatic cirrhosis. Lancet ii:1004-1006, 1989.

121 Vargas V, Castells L, Esteban JI. High frequency of antibodies to the hepatitis $C$ virus among patients with hepatocellular carcinoma. Ann Intern Med 112:232-233, 1990.

122 Colombo M, Kuo G, Choo QL et al. Prevalence of antibodies to hepatitis $\mathrm{C}$ virus in Italian patients with hepatocellular carcinoma. Lancet ii:1006-1008, 1989.

123 Simonetti RG, Cottone M, Craxi A et al. Prevalence of antibodies to hepatitis $\mathrm{C}$ virus in hepatocellular carcinoma. Lancet ii:1338, 1989.

124 Watanabe Y, Harada S, Saito I, Miyamura T. Prevalence of antibody against the core protein of hepatitis $\mathrm{C}$ virus in patients with hepatocellular carcinoma. Int J Cancer 48: 340-343, 1991.

125 Nishioka K, Watanabe J, Furuta S et al. A high prevalence of antibody to the hepatitis $\mathrm{C}$ virus in patients with hepatocellular carcinoma in Japan. Cancer 67:429-433, 1991.

126 Saito I, Miyamura T, Ohbayashi A et al. Hepatitis C virus infection is associated with the development of hepatocellular carcinoma. Proc Natl Acad Sci USA 87: 6547-6549, 1990.

127 Nalpas B, Driss F, Pol S et al. Association between HCV and HBV infection in hepatocellular carcinoma and alcoholic liver disease. J Hepatol 12:70-74, 1991.

128 Hasan F, Jeffers LJ, De Medina M et al. Hepatitis C-associated hepatocellular carcinoma. Hepatology 12: 589-591, 1990.

129 Kuhnl P, Seidl S, Stangel W et al. Antibody to hepatitis C virus in German blood donors. Lancet ii:324, 1989.

130 Janot C, Courouce AM, Maniez M. Antibodies to hepatitis C virus in French blood donors. Lancet ii:796-797, 1989.

131 Sirchia G, Bellobuono A, Giovanetti A et al. Antibodies to hepatitis C virus in Italian blood donors. Lancet ii:797, 1989.

132 Kew MC, Houghton M, Choo QL, Kuo G. Hepatitis C virus antibodies in southern African blacks with hepatocellular carcinoma. Lancet 335:873-874, 1990

133 Chuang WL, Chang WY, Lu SN et al. The role of hepatitis B and $\mathrm{C}$ viruses in hepatocellular carcinoma in a hepatitis B endemic area. Cancer 69:2052-2054, 1992.

134 Tanaka K. Hirohata T, Koga S et al. Hepatitis C and hepatitis $B$ in the etiology of hepatocellular carcinoma in the Japanese population. Cancer Res 51:2842-2847, 1991.

135 Kaklamani E, Trichopoulos D, Tzonou A et al. Hepatitis B and $C$ viruses and their interaction in the origin of hepatocellular carcinoma. JAMA 265:1974-1976, 1991.

136 Zavitsanos X, Hatzakis A, Kaklamani E et al. Association between hepatitis $\mathrm{C}$ virus and hepatocellular carcinoma using assays based on structural and nonstructural hepatitis $C$ virus peptides. Cancer Res 52:5364-5367, 1992.

137 Yu MC, Tong MJ, Coursaget $P$ et al. Prevalence of hepatitis B and $C$ viral markers in black and white patients with hepatocellular carcinoma in the United States. J Natl Cancer Inst 82:1038-1041, 1990.

138 Di Bisceglie AM, Order SE, Klein JL et al. The role of chronic viral hepatitis in hepatocellular carcinoma in the United States. Am J Gastroenterol 86:335-338, 1991.

139 Weiner AJ, Kuo G, Bradley DW et al. Detection of hepatitis C viral sequences in non-A, non-B hepatitis. Lancet 335:1-3, 1990.

140 Aach RD, Stevens CE, Hollinger FB et al. Hepatitis C virus infection in post-transfusion hepatitis: an analysis with first- and second-generation assays. N Engl J Med 325:1325-1329, 1991.

141 McFarlane IG, Smith HM, Johnson PJ et al. Hepatitis C virus antibodies in chronic active hepatitis: pathogenetic factor or false positive result? Lancet 335: 754-757, 1990.

142 Lok ASF, Ma OCK, Chan TM et al. Overestimation of the prevalence of antibody to hepatitis $\mathrm{C}$ virus in retrospective studies on stored sera. Hepatology 14:756-762, 1991.

143 Alter HJ, Purcell RH, Shih JW et al. Detection of antibody to hepatitis $\mathrm{C}$ virus in prospectively followed transfusion recipients with acute and chronic non- $A$, non-B hepatitis. $N$ Engl J Med 321:1494-1500, 1989.

144 Alberti A, Morsica G, Chemello L et al. Hepatitis C viraemia and liver disease in symptom-free individuals with anti-HCV. Lancet 340:697-698, 1992

145 Houghton M, Weiner A, Han J et al. Molecular biology of the hepatitis $\mathrm{C}$ viruses: implications for diagnosis, development and control of viral disease. Hepatology 14:381-388, 1991.

146 Fong TL, Di Bisceglie AM, Waggoner JG et al. The significance of antibody to hepatitis $\mathrm{C}$ virus in patients with chronic hepatitis B. Hepatology 14:64-67, 1991.

147 Newberne PM, Butler WH. Acute and chronic effects of aflatoxin on the liver of domestic and laboratory animals: a review. Cancer Res 29:236-250, 1969.

148 Wogan GN, Newberne PM. Dose-response characteristics of aflatoxin $B_{1}$ carcinogenesis in rat. Cancer Res 27:2370-2376, 1967.

149 Peers $\mathrm{F}$, Bosch $\mathrm{X}$, Kaldor $\mathrm{J}$ et al. Aflatoxin exposure, hepatitis $B$ virus infection and liver cancer in Swaziland. Int $J$ Cancer 39:545-553, 1987.

150 Autrup H, Seremet T, Wakhisi J, Wasunna A. Aflatoxin exposure measured by urinary excretion of aflatoxin $B_{1}$-guanine adduct and hepatitis B virus infection in areas with different liver cancer incidence in Kenya. Cancer Res 47:3430-3433, 1987.

151 Yeh FS, Yu MC, Mo CC et al. Hepatitis B virus, aflatoxins, and hepatocellular carcinoma in southern Guangxi, China. Cancer Res 49:2506-2509, 1989.

152 Campbell TC, Chen J, Liu C et al. Nonassociation of aflatoxin with primary liver cancer in a cross-sectional ecological survey in the People's Republic of China. Cancer Res 50:6882-6893, 1990.

153 Groopman JD, Jiaqi Z, Donahue PR et al. Molecular dosimetry of urinary aflatoxin-DNA adducts in people living in Guangxi 
autonomous region, People's Republic of China. Cancer Res 52:45-52, 1992.

154 Wild CP, Jiang YZ, Sabbioni $G$ et al. Evaluation of methods for quantitation of aflatoxin-albumin adducts and their application to human exposure assessment. Cancer Res 50:245-251, 1990.

155 Sell S, Hunt JM, Dunsford HA, Chisari FV. Synergy between hepatitis $B$ virus expression and chemical hepatocarcinogens in transgenic mice. Cancer Res 51:1278-1285, 1991.

156 Croy RG, Essigmann JM, Wogan GN. Aflatoxin $B_{1}$ : correlations of patterns of metabolism and DNA modification with biologic effects. Basic Life Sci 24:49-62, 1983.

157 Gurtoo HL, Motycka L. Effect of sex differences on the in vitro and in vivo metabolism of aflatoxin B1 by the rat. Cancer Res 36:4663-4671, 1976.

158 Sinha $S$, Webber $C$, Marshall $C J$ et al. Activation of ras oncogene in aflatoxin-induced rat liver carcinogenesis. Proc Natl Acad Sci USA 85:3673-3677, 1988.

159 Chang YJ, Mathews C, Mangold K et al. Analysis of ras gene mutations in rainbow trout liver tumors initiated by aflatoxin $B_{1}$. Mol Carcinogen 4: 112-119, 1991.

160 Bressac B, Kew M, Wands J, Ozturk M. Selective G- to Tmutations of $\mathrm{p} 53$ gene in hepatocellular carcinoma from southern Africa. Nature (London) 350:429-431, 1991.

161 Berman JJ. Cell proliferation and the aetiology of hepatocellular carcinoma. J Hepatol 7:305-309, 1988.

162 De Flora S, Hietanen E, Bartsch $\mathrm{H}$ et al. Enhanced metabolic activation of chemical hepatocarcinogens in woodchucks infected with hepatitis B virus. Carcinogenesis 10: 1099-1106, 1989.

163 De Flora S, Romano M, Basso C et al. Metabolic activation of hepatocarcinogens in chronic hepatitis B. Mutat Res 144:213-219, 1985.

164 Lee HS, Sarosi I, Vyas GN. Aflatoxin $B_{1}$ formamidopyrimidine adducts in human hepatocarcinogenesis: a preliminary report. Gastroenterology 97:1281-1287, 1989.
165 Zhang YJ, Chen CJ, Lee CS et al. Aflatoxin $B_{1}$-DNA adducts and hepatitis $B$ virus antigens in hepatocellular carcinoma and non-tumorous liver tissue. Carcinogenesis 12:2247-2252, 1991.

166 Tzonou A, Trichopoulos D, Kaklamani E et al. Epidemiologic assessment of interaction of hepatitis- $C$ virus with seromarkers of hepatitis-B and $-D$ viruses, cirrhosis and tobacco smoking in hepatocellular carcinoma. Int J Cancer 49:377-380, 1991.

167 Robinson WS, Miller RH, Marion PL. Hepadnaviruses and retroviruses share genome homology and features of replication. Hepatology 7:64S-73S, 1987.

168 Muchmore E, Popper H, Peterson DA et al. Non-A, non-B hepatitis-related hepatocellular carcinoma in a chimpanzee. $J$ Med Primatol 17:235-246, 1988.

\section{Biographies}

Ming-Whei $Y u$ received a $\mathrm{Ph} . \mathrm{D}$. degree from the College of Medicine, National Taiwan University. She completed her post-doctoral training in the Division of Environmental Sciences, School of Public Health, Columbia University. She is currently the Associate Professor in the Institute of Epidemiology College of Public Health, National Taiwan University. Chien-Jen Chen received a Sc.D. degree from the School of Hygiene and Public Health, Johns Hopkins University. He was an International Fogarty Research Fellow in the Division of Environmental Sciences, School of Public Health, Columbia University. He is currently the Professor and Director Institute of Epidemiology in the College of Public Health, National Taiwan University and a Fellow of the American College of Epidemiology. 